\title{
Outbreak investigations and molecular characterization of foot-and-mouth disease viruses circulating in southwest Niger
}

Bachir Souley Kouato ${ }^{1,7}$, Elliot Mpolokang Fana ${ }^{2}$, Donald P. King ${ }^{3}$, Joseph Hyera ${ }^{2}$, Nick J. Knowles ${ }^{3}$, Anna B. Ludi ${ }^{3}$, Valérie Mioulet ${ }^{3}$, George Matlho ${ }^{2}$, Kris De Clercq ${ }^{4}$, Eric Thys ${ }^{5}$, Hamani Marichatou ${ }^{6}$, Salissou Issa ${ }^{7}$, Claude Saegerman ${ }^{1}$

${ }^{1}$ Research Unit in Epidemiology and Risk Analysis Applied to Veterinary Sciences (UREAR-ULg), Fundamental and Applied Research for Animals \& Health (FARAH) Centre, Faculty of Veterinary Medicine, University of Liege, Liege, Belgium

${ }^{2}$ Botswana Vaccine Institute, Private Bag 0031, Gaborone, Botswana

${ }^{3}$ The Pirbright Institute, Ash Road, Pirbright, Woking, Surrey, GU24 0NF, UK

${ }^{4}$ Operational Directorate Viral Diseases, Veterinary and Agrochemical Research Centre (CODACERVA), Brussels, Belgium

${ }^{5}$ Department of Biomedical Sciences, Institute of Tropical Medicine, Antwerp, Belgium

${ }^{6}$ Université Abdou Moumouni de Niamey, Faculté d'Agronomie, Niamey, Niger

${ }^{7}$ Institut National de la Recherche Agronomique du Niger (INRAN), Niamey, Niger

*Correspondence: Prof. Claude SAEGERMAN, UREAR-ULg, Fundamental and Applied Research for Animals \& Health (FARAH) Center, Faculty of Veterinary Medicine, University of Liege, Quartier Valley 2, Avenue de Cureghem 7 A, B42, B-4000 Liege, Belgium; Tel.: +32 436645 79; Fax: +32 4 36642 61; E-mail: claude.saegerman@ulg.ac.be 


\begin{abstract}
In Niger, the epidemiological situation regarding foot-and-mouth disease is unclear since many outbreaks are unreported. This study aimed i) to identify FMDV strains currently circulating in cattle herds, and ii) to identify risk factors associated with FMD seropositive animals in clinical outbreaks. Epithelial tissues $(n=25)$ and sera $(n=227)$ were collected from cattle in eight districts of the southwestern part of Niger. Testing of clinical material revealed the presence of FMDV serotype $\mathrm{O}$ that was characterised within the O/WEST AFRICA topotype. The antigenic relationship between one of the FMDV isolates from Niger (O/NGR/4/2015) and three reference vaccine strains was determined by the two-dimensional virus neutralization test $(2 \mathrm{dmVNT})$, revealing a close antigenic match between the field isolate from Niger and three FMDV serotype O vaccine strains. Serological analyses using a non-structural protein (NSP) test provided evidence for previous FMDV infection in $70 \%(158 / 227)$ of the sera tested. Multivariate logistic regression analysis revealed that only the herd composition (presence of both cattle and small ruminants) was significantly associated with FMDV seropositivity as defined by NSP positive results $(\mathrm{P}-\mathrm{value}=0.006)$. Of these positive sera, subsequent testing by Liquid Phase Blocking ELISA (LPBE) showed that 86\% (136/158) were positive for one (or more) of four FMDV serotypes (A, O, SAT 1 and SAT 2). This study provides epidemiological information about FMD in the southwestern part of Niger, and highlights the complex transboundary nature of FMD in Africa. These findings may help to develop effective control and preventive strategies for FMD in Niger as well, as other countries in West Africa.
\end{abstract}

Keywords: Foot-and-Mouth Disease Virus; Identification, Molecular Characterization; Serology; Risk factors, southwestern Niger. 


\section{Introduction}

Foot-and-mouth disease (FMD) is a highly contagious transboundary disease of cloven-hoofed domestic and wild animals caused by FMD virus (FMDV) belonging to the Aphthovirus genus within the Picornaviridae family. FMDV is a small, non-enveloped, icosahedral virus that has a positive-sense, single-stranded RNA genome of approximately $8.5 \mathrm{~kb}$ that encodes a single polyprotein which is cleaved into four structural proteins (SP) and 10 non-structural proteins (NSPs) by virus encoded proteases (Belsham, 1993). FMDV exists in seven immunologically distinct serotypes, O, A, C, Asia 1, SAT (Southern African Territories) 1, SAT 2 and SAT 3, each with a wide range of antigenically distinct subtypes. (Gleeson, 2002; Kasambula et al., 2012; Knowles \& Samuel, 2003).

FMD is endemic in Niger where clinical disease has been reported mainly in cattle (CouacyHymann et al., 2006; Sangare et al., 2001; Sangare et al., 2004a). FMD was first reported in Niger in 1945, when samples corresponding to serotype C were typed by the Laboratoire Central de Recherches Vétérinaires of Maisons-Alfort in France (Pagot, 1948). According to a retrospective study that reviewed FMD outbreaks occurring between 1971 and 2001 (CouacyHymann et al., 2006), four FMDV serotypes (namely O, A, SAT 1 and SAT 2) were suspected to be present in West African countries including Niger. Other published studies support the circulation of these four FMD serotypes in the region (Fasina et al., 2013; Gorna et al., 2014; Olabode et al., 2014; Sangare et al., 2001; Sangare et al., 2003; Sangare et al., 2004a, Sangare et al., 2004b; Ularamu et al., 2016), although a comprehensive understanding of FMD epidemiology that can be used to inform disease control programs is currently lacking. Unfortunately, livestock in Niger have never been vaccinated against FMD. Moreover, as the livestock production system is mostly characterized by transhumance, nomadism and trade with neighbouring countries, there are no restrictions on animal movements in the country or elsewhere in West African. Therefore, the objectives of this study were to identify FMDV strains responsible for outbreaks in the southwestern part of Niger that occurred in cattle in 2014, as well as to describe risks factors associated with FMDV seropositivity in animals from these herds. 


\section{Materials and methods}

\section{Study area}

In this article, sampling locations were defined at the district-level (Niger is administratively divided into 8 regions, 63 departments and 265 districts). The study was conducted in eight districts in the southwestern part of the country that included three regions namely Niamey (the capital), Tillabery and Dosso.

It is in the region of Tillabery that the largest numbers of samples were obtained in four districts: Kollo located $35 \mathrm{~km}$ from Niamey, Makalondi, Tamou and Alambaré bordering with Burkina Faso. In addition, Tamou and Alambaré are located near the W Regional Park which is a major national park in West Africa (Niger, Burkina Faso and Benin) around a meander in the River Niger shaped like a "W". In the Dosso region, three districts were involved in the study, including Dole, Tanda and Gaya, which share a common border with Nigeria and Benin. In Niamey, one district (called the fourth Arrondissement) was involved. Except for Niamey's district, these localities are located either on the transhumance route towards Benin and Nigeria (districts of Tanda, Dole and Gaya), or towards Burkina Faso and Benin (districts Tamou, Alambaré and Makalondi). This zone covers an area of more than $29,000 \mathrm{~km}^{2}$ with a cattle population of about 500,000 animals (representing 5\% of the cattle population at national level) based on the latest livestock census in 2007. Agriculture and livestock are the main activities of the resident population. The study area is depicted in Figure 1.

Insert figure 1: Geographical locations of FMD outbreaks described in this study

\section{Sampling design and disease investigation}

In this study, an outbreak was defined as a district from which one or more clinical cases of FMD were reported by the district animal health service and/or by the farmers themselves. During September to October 2014, all reported outbreak sites were visited as soon as possible after notification; epithelium and serum samples were collected from cattle in the described study area.

As far as we are aware, no FMDV vaccination or other control measures were implemented at the study sites as in other parts of the country. The animals were first examined for evidence of salivation and lameness. Salivating and/or lame animals were restrained in a crush pen for thorough examination and sampling. The oral cavity of salivating animals was examined for 
evidence of intact and/or ruptured vesicles, erosions and ulcers on the tongue, dental pad and mucosa. The hooves of lame animals were thoroughly washed with water and carefully examined for lesions, particularly on the coronary bands and interdigital spaces of the hooves. The epithelium samples were taken from sick animals showing suspected clinical signs and lesions of FMD, while the sera were taken from all examined animals during the herd visit, including those on which epithelium samples were collected (Table 1).

Insert Table 1: Overview of the sampling strategy

\section{Sample and data collection}

Twenty-five epithelium tissues were collected from oral and foot lesions from suspected FMDinfected cattle in seven separate districts: Makalondi $(n=7)$, Gaya $(n=2)$, Dolé $(n=1)$, Tanda $(n=1)$, Kollo $(n=7)$, Alambaré $(n=5)$ and Tamou $(n=2)$. After collection, the tissues were immediately placed in a virus transport media composed of equal amount of sterile glycerol (50\% v/v) and $0.04 \mathrm{M}$ phosphate buffered saline (PBS) at a pH between 7.2 and 7.6.

At the same time, 227 blood samples were collected from apparently healthy and from clinically affected cattle. Sera were collected in eight districts (seven mentioned above and in one of the districts of Niamey): Makalondi ( $n=38)$, Gaya ( $n=5)$, Dolé $(n=19)$, Tanda ( $n=17)$, Kollo $(n=48)$, Alambaré $(n=14)$, Tamou $(n=10)$ and Niamey $(n=51)$. In the last district, Niamey, the FMD outbreak was notified at least three weeks after the occurrence of the active outbreak and at the time of the visit there were neither clinical signs nor lesions in affected cattle. The samples (serum and epithelium) were transported to the National Veterinary Laboratory of Niamey (LABOCEL) on dry ice. At LABOCEL, samples were stored at $-20^{\circ} \mathrm{C}$ (serum) and at $-80^{\circ} \mathrm{C}$ (epithelium) until their shipment to the Botswana Vaccine Institute (BVI) laboratory for analyses. All specimens were packaged as described by Kitching and Donaldson (1989) and shipped in a transport media to the BVI laboratory in Gaborone, Republic of Botswana. Among the epithelium tissues, positive samples diagnosed at BVI were submitted for confirmation to the World Reference Laboratory for FMD (WRLFMD) at The Pirbright Institute, UK.

Data were collected using a questionnaire (see Appendix 1), which was used to interview farmers responsible for 28 herds (with a total of 227 sampled animals) selected on the basis of FMD outbreak notification. The recorded data included animal age, sex and location, and the presence or absence of clinical signs and lesions in cattle. In addition, the interview collected information regarding FMD risk factors such as the number of animals in the herd, the herd 
composition, the grazing and watering habits, the herd management (transhumance nomadic or sedentary), and the potential contact with wildlife.

\section{Serological analysis}

\section{Detection of antibodies against FMDV non-structural proteins (NSP-ELISA)}

Serological diagnostics were performed at the Botswana Vaccine Institute (BVI) in accordance to the established standards and practices of this OIE reference laboratory for Sub-Saharan Africa. Sera were initially screened for antibodies against the highly conserved NSP of FMDV using the PrioCHECK® FMDV NS Enzyme-Linked Immunosorbent Assay (ELISA) test kit (Prionics AG, Switzerland), following the manufacturer's protocol. The Optical Density at 450nm (OD450) values of all samples were expressed as Percentage of Inhibition (PI) relative to the OD450 max. Positive results were defined as samples that generated a PI value of $\geq 50$, whereas a strong positive result was set at a PI value of $\geq 70$.

\section{Detection of serotype-specific antibodies against FMDV Liquid-phase blocking ELISA (LPBE)}

NSP ELISA positive reactive sera were further assessed using the Liquid-Phase Blocking ELISA (LPBE) modified from Hamblin et al. (1986). Briefly, ELISA plates NUNC Maxisorp (Gibco, Cat\#4-39454A) were coated with FMDV serotype-specific rabbit hyperimmune sera (serotypes O, A, SAT1 and SAT2 suspected to be present in Niger), and left overnight in a humid chamber at room temperature. In carrier plates, 2-fold series of each test serum were prepared, from 1/16 to 1/128. Control sera (strong and weak positive, and negative) were diluted at $1 / 16$. To each well of the carrier plate, $50 \mu 1$ the different FMDV serotype viral antigen was added at a pre-determined working dilution, resulted in a ratio of sera with FMD antigen starting from $1 / 32$ to $1 / 256$. The following day, the rabbit antiserum-coated ELISA plates were washed three times with phosphate buffered saline containing 0.05\% Tween 20 (PBST) (pH 7.4), and serum/antigen mixtures were transferred from the carrier plates to the rabbit-serum-coated ELISA plates and incubated at $37^{\circ} \mathrm{C}$ for 1 hour on a rotary shaker. The plates were then washed three times as previously and FMDV serotype-specific guinea pig antiserum was added to each well at a predetermined working concentration and incubated at $37{ }^{\circ} \mathrm{C}$ for 1 hour on a rotary shaker. After incubation and washing step as previously, rabbit anti-guinea pig immunoglobulin conjugated to horseradish peroxidase was added to each well at a predetermined working concentration. The plates were washed after 1 hour of incubation and substrate solution (orthophenylene diamine [OPD] $+0.05 \% \mathrm{H}_{2} \mathrm{O}_{2}$ ) was added to each well. The reaction was 
stopped by adding $50 \mu \mathrm{l}$ of $1 \mathrm{M}$ sulfuric acid. The plates were read at $492 \mathrm{~nm}$ on a Thermo Scientific ${ }^{\mathrm{TM}}$ Multiskan ${ }^{\mathrm{TM}}$ FC Microplate Photometer and antibody titres were expressed as the final dilution of the tested serum giving $50 \%$ of the mean absorbance value in the virus control wells where test serum was absent. Titres of less than $1 / 40$ (or 1.6 in reciprocal $\log _{10}$ form) were considered as negative while titres more than 1/40 were considered positive (Hamblin et al., 1986).

\section{Analysis of epithelium tissues}

\section{Virus isolation}

The epithelium tissues were processed by the standard WRLFMD/World Organisation for Animal Health (OIE) procedure for virus isolation (OIE, 2012). The composition of the media used for virus isolation and culture of cells is as follows: 10\% Minimum Essential Medium 10X (MEM 10X), 10\% Lactalbumin Hydrolysate 10X, 4.5\% Sodium Bicarbonate, $1 \%$ Negative Calf serum, $0.2 \%$ Penicillin and top up to $100 \mathrm{ml}$ with sterile distilled water. The epithelium samples were first taken from the PBS/glycerol, and blotted dry on absorbent paper. A suspension was prepared by grinding 1 gram of the sample in sterile sand in a sterile pestle and mortar with a small volume of tissue culture medium. Medium was added until a final volume of nine times that of added epithelial sample was reached, giving a $10 \%$ suspension. The suspension was clarified on a bench centrifuge at 3,700 RPM for 10 minutes at $4^{\circ} \mathrm{C}$. The clarified suspensions suspected to contain FMDV were inoculated onto primary lamb kidney cell cultures (Rein de Mouton [RM]: at BVI) or primary bovine thyroid cell cultures (BTy: at WRLFMD) and incubated for 1 hour at $37^{\circ} \mathrm{C}$. Fresh cell culture medium was then added $(15 \mathrm{ml})$; the cultures were incubated at $37^{\circ} \mathrm{C}$ and monitored for cytopathic effect (CPE) for 48 hours. If no CPE was observed after 48 hours, the sample was considered as 'no virus detected' the culture was frozen at $-70^{\circ} \mathrm{C}$, then thawed and centrifuged at $3,700 \mathrm{RPM}$ for 10 minutes at $4{ }^{\circ} \mathrm{C}$ to collect supernatant for second passage (P2), this was repeated for third passage (P3) and if no CPE was observed at $48 \mathrm{hrs}$, then the sample was considered negative for FMDV. The first passage (P1) and the second passage (P2) were subject to one freeze-thaw cycle. If CPE was observed, the culture medium was pooled and cleared by centrifugation at $3,700 \mathrm{RPM}$ for 10 minutes at $4^{\circ} \mathrm{C}$. A sample of supernatant was tested by RT-PCR following RNA extraction. However, it should 
be noted that the samples were examined for virus isolation nine months after they had been collected in the field.

\section{Conventional RT-PCR assay for VP1 analysis}

RNA was extracted from the ground tissue suspension samples using ZR Viral RNA kit (ZymoResearch, USA) following the manufacturer's instructions. Extracted nucleic acid samples were analysed for FMDV RNA using conventional reverse transcription-polymerase chain reaction (RT-PCR) using oligonucleotide forward primer O-1C244F (5'GCAGCAAAACACATGTCAAACACCTT-3') and reverse primer EUR 2B-52R (5'GACATGTCCTCCTGCATCTGGTTGAT-3') targeting the VP1 gene within the FMDV RNA genome (Knowles et al., 2016). At the BVI, the RT-PCR was set and ran as following: reverse transcription at $48^{\circ} \mathrm{C}$ for 30 minutes; the initial denaturation at $94^{\circ} \mathrm{C}$ for 1 minute; 40 cycles (denaturation at $94^{\circ} \mathrm{C}$ for 15 seconds; annealing at $60^{\circ} \mathrm{C}$ for 30 seconds; extension at $68^{\circ} \mathrm{C}$ for 1 minute); a final extension at $68^{\circ} \mathrm{C}$ for 5 minutes and then hold at $4^{\circ} \mathrm{C}$. Amplification products were separated on a $1.5 \%$ agarose gel and visualised by Gel Red staining and UV irradiation. One-step RT-PCR at the WRLFMD was performed as previously described (Knowles et al., 2016).

\section{Sequencing and phylogenetic analysis}

The RT-PCR amplicons were sequenced on both strands as previously described (Knowles et al., 2016). The sequences were assembled and verified using SeqMan software (DNAStar, Lasergene v.8). VP1 nucleotide sequences were aligned by using BioEdit version 7.2.5 (Hall, 1999) and Clustal W (Thompson et al., 1994).

The comparison and midpoint-rooted Neighbor-joining trees of FMDV VP1 sequences from Niger with those from Africa available in the NCBI GenBank database (www.ncbi.nlm.nih.gov) were performed using MEGA 6.06 (Tamura et al., 2013). The robustness of tree topology was assessed with 1000 bootstrap replicates by using the model in MEGA 6.06. Bootstrap values of $>70$ are shown at the relevant major nodes. Sequences showing $100 \%$ nucleotide identity in VP1 were classified as a single genetic variant. The complete VP1 nucleotide sequences generated in this study corresponding to each genetic variant but also collected from a specific geographic location were submitted to the NCBI GenBank database under the accession numbers (KX424677-KX424682). 


\section{Vaccine Strain Selection}

Vaccine strain selection for serotype $\mathrm{O}$ isolates was performed at WRLFMD by twodimensional virus neutralization test (2D-VNT). The vaccines used in this study were provided by international vaccine manufacturers (Merial Animal Health and Merck Animal Health). The 2D-VNT test was carried out using the pooled post-vaccination monovalent bovine vaccine sera (BVS) collected after 21 days post-vaccination of naïve animals. Briefly, the BVS was tested against both the homologous (vaccine strains) and the heterologous (field strain). Antibody titres of the reference serum against the homologous (reference) and heterologous (field) viruses for five virus doses were calculated, and a linear regression line was drawn (Minitab program) to allow the $\log _{10}$ reciprocal antibody dilution required for $50 \%$ neutralization of 100 tissue culture infective units $\left(\mathrm{TCID}_{50}\right)$ of virus to be calculated. The antigenic relationship between the field strain and the reference strain was then expressed as an ' $r_{1}$ ' value based on the following equation: "Reciprocal $\log _{10}$ of (heterologous titre - homologous titre)" (Rweyemamu et al., 1976). An $r$ value of $>0.3$ suggests that the vaccine virus may protect against the field strain (Paton et al., 2005).

\section{Statistical analysis}

In a first step, a multilevel mixed-effects model was used to take into account the possible herd and/or district levels as random effects. Because random effects were not observed, logistic regression was used to model the odds of being NSP positive as a function of investigated potential exposure risk factors. Initial screening of potential risk factors for FMD was performed by univariate regression (Hosmer \& Lemeshow, 2000). Secondly a multivariate logistic regression using backward stepwise analysis was used to check the relationship between NSP positive results and explanatory variables (Petrie, 2006). The following explanatory variables and their respective reference classes were used: province of origin of the herd $\left(4^{\text {th }}\right.$ Arrondissement as reference), herd type (nomadism or transhumance as reference), herd size (continue variable), herd composition (only cattle as reference), contact with wildlife (rare as reference), transhumance destination (inside the country as reference), detection for FMD cases after the transhumance (yes as reference), gender (male as reference), age ( $\leq 2$ years as reference), animal origin (birth inside the herd as reference), clinical signs (presence as reference) and lesions (presence as reference). In addition, to assess the collinearity, a backward elimination of variables was performed (Preux, 2005). If a variable induced a modification of the odds ratio of more than $20 \%$, this variable was retained in the final model where the interaction was tested in case of biological relevance. Goodness of fit was assessed using the 
Hosmer-Lemeshow goodness-of-fit test. Statistical analyses were performed using STATA/SE Acad. 14 (Stata Corp., College Station, Texas, USA).

\section{Results}

\section{Characteristics of sampled animal}

A total of 227 cattle including 93 males (41\%) and 134 females (59\%) belonging to 28 herds (20 transhumant or nomadic herds and 8 sedentary herds) were sampled during the period between September 4, 2014 and October 16, 2014. Most of the sampled animals were relatively young as the age of $58 \%(n=132)$ was estimated between 0 and 2 years, while $42 \%(n=95)$ had an estimated age between 3 and 4 years or more. Only 15\% $(n=33)$ of the sampled animals were introduced into their respective herds from outside, via purchase from livestock markets. With respect to animal species composition, 7 out of the 28 of the sampled herds were composed only of cattle, while the 21 of the other herds were mixed ( 8 herds with cattle and small ruminants and 13 herds with cattle, small ruminants and other animals such as poultry, camels and horses). In Makalondi District, a single mixed herd included pigs. All the sampled animals of the selected herds mixed with animals of other herds of neighbouring districts during grazing and access to water points. According to herdsmen, in more than half of the selected herds (54\%, $\mathrm{n}=15)$, clinical cases of FMD were reported when the cattle came back from transhumance. Of the total of 227 animals tested, 38 animals (17\%) exhibited both clinical signs and lesions of FMD. Accordingly, it was among these 38 animals that sufficient epithelium samples were taken from 25 sick cattle.

\section{Serological analysis}

Using the NSP ELISA test, 70\% (158/227) of sera were positive for the presence of antibodies against FMDV. There was random distribution of positive animals among age classes (Chisquare $(3 \mathrm{df})=6.12 ; \mathrm{p}=0.11)$. The seroprevalence of animals of the age group between 3 and 4 years $(83 \%)$ was not significantly higher than the prevalence of animals of other age categories $(70 \%, 62 \%$ and $65 \%$ for $\leq 2$ years, $>2$ and $\leq 3$ years and $>4$ years respectively)

Table 2.

Insert Table 2: NSP ELISA positive animals by age class

Among the NSP ELISA positive sera tested by LPBE, 86\% (136/158) were positive for one or more serotypes (A, O, SAT 1 and SAT 2). Based on the distribution of seroprevalence by 
sampling site, the highest serological prevalence was for serotype $\mathrm{O}$ observed in $7 / 8$ districts (except the district of Tamou) (Figure 2).

Insert Figure 2: Liquid Phase Blocking ELISA results based on geographical locations of FMD outbreaks

In addition, either as single or as multiple serological reactions, there was a clear dominance of serotype $\mathrm{O}$ followed by serotypes A and SAT1. However, only $11.3 \%(\mathrm{n}=18)$ of NSP ELISA positive samples yielded positive results for a single serotype: against serotypes A ( 5 samples), SAT1 (4 samples) or O (9 samples), while $86.1 \%(n=136)$ were positive for 2 or more serotypes, and only $2.5 \%(n=4)$ generated negative results with the LPBE (Figure 3 and Appendix 2).

Insert Figure 3: Prevalence of single or multiple FMDV serotypes detected in LPBE

\section{Factors associated with FMDV seropositivity based on a logistic regression analysis}

The results of univariate regression analysis for odds of being NSP ELISA positive as a function of investigated potential exposure risk factors showed that only the herd composition (presence of both cattle and small ruminants) was highly significantly associated with FMDV seropositivity ( $\mathrm{p}=0.002$; Table 3 ). The remaining variables were not significantly associated with FMDV seropositivity at the $5 \%$ level, but those with a p-value $\leq 0.2$ were considered as potential risk factors and therefore entered in the multivariable analysis model (herd composition, district of origin and age of animals).

Insert Table 3: Potential risk factors associated with FMDV seropositivity based on a univariate logistic regression model

Multivariate analysis including all variables (with a p-value less than 0.20 after univariate analysis) exploited a final model that included district and herd composition as variables. Herd composition was significantly associated with FMDV positivity $(\mathrm{p}=0.006)$. The HosmerLemeshow test showed that this final model fitted the data well (Chi-square $=1.81$; $\mathrm{df}=6$, Pvalue $=0.94)$. The interaction between the two retained variables was not tested because of the lack of biological relevance (Table 4). 
Insert Table 4: Final model of risk factors associated with FMDV seropositivity based on a multivariate logistic regression model

\section{Isolation and identification of FMDV}

Thirteen of the 25 epithelial samples produced CPE during one, two or three passages on primary lamb kidney cell cultures at BVI. These samples were from the districts of Tamou (3), Gaya (2), Makalondi (2) and Kollo (6). By antigen ELISA (performed at the WRLFMD), FMDV serotype $\mathrm{O}$ was identified in cell culture harvests from seven epithelia collected in Gaya $(n=1)$, Makalondi $(n=2)$ and Kollo $(n=4)$ districts. Based on the sequence comparison using BLAST, the serotype identification of these samples was in concordance with the Ag-ELISA results. The other six samples (from the $13 \mathrm{CPE}$ positive samples) were detected negative by both antigen ELISA and PCR tests. Sequences were obtained for six of the seven isolates of FMDV serotype $\mathrm{O}$, and these are included in the phylogenetic analysis and listed in Table $\mathbf{5}$

Insert Table 5: Diagnostic results on epithelium samples collected in Niger in 2014 and the GenBank accession number of VP1 sequences

\section{Phylogenetic analysis}

From FMDV isolates collected in 2014, amplicons corresponding to the complete VP1 coding region were generated by RT-PCR and sequenced for six of the virus isolates. These sequences were compared with others from NCBI, GenBank and results from phylogenetic analyses revealed that they all belonged to the topotype O/West Africa (WA). Those isolated from Kollo district (NGR/4/2015, NGR/21/2015 and NGR/24/2015) had pairwise alignment (nt) identities of $99.3 \%-99.7 \%$ with each other while the viruses isolated from Makalondi (NGR/15/2015 and NGR/16/2015) had 100\% nt identity with each other. The FMDV isolate from Gaya (NGR/11/2015) had pairwise nt identity of $99.0 \%-99.4 \%$ with other isolates from other districts. The VP1 sequences from Niger were compared to those available in the GenBank database (Figure 4). The analysis revealed that the Niger isolates are mostly related to the FMDV from Benin [O/BEN/40/2010 (KC832986) with $95.2 \%$ to $95.8 \%$ nt identity and O/BEN/26/2010 (KC832981) with $94.2 \%$ to 95.8\% nt identity], Togo [O/TOG/1/2004 (KX258038) with $90.3 \%$ to $92.3 \%$ nt identity and O/TOG/1/2005 (KX258039) with $92.1 \%$ nt identity] and from Ghana [O/Lam/GHA/2012 (KF305227) with 90.3\% to 90.9\% nt identity] all being classified within the type O/WA topotype. However, the Niger FMDV isolates show lower relationship values with other earlier West African FMDV serotype O isolates from Côte 
d'Ivoire [O/CIV/8/99 (AJ303485) with $88.9 \%$ to $90.4 \%$ nt identity] and from Ghana [O/GHA/5/93 (AJ303488) with $85.8 \%$ to $87.4 \%$ nt identity] (Figure 4).

Insert Figure 4: Midpoint-rooted Neighbor-joining tree showing the relationship between the VP1 sequences of serotype $\mathrm{O}$ isolated in Niger

\section{Vaccine Strain Selection}

The antigenic relationship between one of the FMDV isolates from Niger (O/NGR/4/2015) and three reference vaccine strains were determined by the two-dimensional virus neutralization test (2D-VNT). The results presented (Table 6) revealed that there is a close antigenic relationship between the three FMDV serotype $O$ vaccine strains and Niger's FMDV serotype $\mathrm{O}$ field isolate. The calculated ' $r_{1}$ ' value was greater than the minimum requirement $(>0.3)$ for especially the two vaccine strains (O3039 and O/TUR/5/2009).

Insert Table 6: ' $\mathrm{r} 1$ ' values obtained between FMDV serotype $\mathrm{O}$ field isolates and vaccine strains

\section{Discussion}

This study reports on serological and molecular information for FMD outbreaks in southwest Niger based on samples collected from cattle in September and October 2014. FMD is endemic in most parts of Africa and only few countries in the south of the continent have managed to control the disease (Brito et al., 2015; Vosloo et al., 2002), while only sporadic cases of FMD are regularly reported (Brito et al., 2015; Tekleghiorghis et al., 2016). Niger with an area of $1,267,000 \mathrm{~km}^{2}$, is one of the largest West African countries. Based on the general census of agriculture and livestock in 2007, the cattle population was estimated at more than 7 million of heads. However, despite the important role of the livestock sector in Niger (La Rovere et al., 2005; Turner \& Williams, 2002), this industry is continuously challenged with multiple constraints such as the persistence of animal diseases, including FMD. Although FMD outbreaks have been reported every year, the veterinary authorities and farmers have placed little emphasis to FMD. Hence, even though FMD is on the list of monitored animal diseases in epidemio-surveillance networks, there is still an under-reporting of FMD outbreaks. The main purpose of this study was to characterize FMD viruses responsible for clinical cases and additionally to have an overview of circulating FMDV antibodies in livestock associated with 
risk factors analysis. This was only the justification of the adopted sampling method that can be designated as a "convenience sampling" consisting therefore to sample suspected sick animals (for epithelial tissues) and both the suspected sick animals and apparently healthy animals (for sera) in the all reported infected herd (as soon as possible after the rare notification of outbreaks). However, despite the limited nature of sampling, this study could certainly have the value to update data on FMD in a country where the epidemiological status of the disease is poorly understood.

The serological results indicate that FMDV is endemic within the livestock population in the study area, suggesting that multiple FMDV serotypes (such as A, O, SAT 1 and SAT 2) may be involved as has been shown elsewhere in the West African region (Brito et al., 2015; Di Nardo et al., 2011; Ehizibolo et al., 2014; Fasina et al., 2013; Gorna et al., 2014). Using the budget available for this study, serological testing (by LPBE) was designed to detect four different FMDV serotypes (A, O, SAT 1 and SAT 2) suspected to be present in Niger. Further studies may be warranted to also include serotypes C and SAT 3, although serotype $\mathrm{C}$ has not been detected in any country since 2004. SAT 3-specific antibodies have been recorded in sera from west and central Africa (Ehizibolo et al., 2014; Ludi et al., 2016) and from eastern Africa (Ayebazibwe et al., 2010; Dhikusooka et al., 2015; Mwiine et al., 2010; Namatovu et al., 2015), although this serotype has not previously been detected in Niger. Although the sampling strategy is different to that implemented by Ludi et al, (2016), our results appear to be similar regarding the presence of different serotypes in unvaccinated animals. Serological tests also reveal that antibodies to four FMDV serotypes were present among the animals sampled although only one FMDV serotype (O) was detected by viral isolation and sequencing. The presence of animals with single serological reactivity to serotypes A and SAT 1 (Figure 3) may indicate either past exposure to these FMDV, or may arise as a result of cross-reactivity among serotypes in the LPBE (Hedger et al, 1982; Jackson et al., 2007). Future serological studies are warranted to these results.

Since 2005, only O and SAT 2 serotypes have been isolated in Niger, serotype A having been isolated for the last time in 1973 and SAT1 in 1976 (WRLFMD, 2016b). In this study, the highest serological prevalence was that of serotype O (89\%), followed by serotypes SAT 1, A and SAT 2. Serotype O was detected in more than $80 \%$ of samples from all selected districts where FMD outbreaks occurred. Furthermore, for individual districts, serotype $\mathrm{O}$ was most frequently detected, except in Gaya and Tanda Districts where serotype A (at 33\%) and serotype 
SAT1 (at 45\%) were found, respectively. Interestingly, specific response to serotype O was obtained in cattle from 3/7 districts, namely Tamou, Kollo and Niamey. Additionally, in Niamey where the epithelium sampling was not possible due to the delay in the notification of the FMD outbreak, five sera were specifically positive to serotype O. The serological results for serotype $\mathrm{O}$, could be interpreted as significant for this study because the serotype $\mathrm{O}$ was the only FMDV detected positive through viral isolation test. However, there is no evidence about any conclusion regarding the serological responses by the fact that the adopted sampling scheme is not consistent to make an accurate statement on statistical inference of results.

There was no association between seropositivity and age. Generally, keeping young animals around the homestead or in areas separated from adult animals helps to decrease their exposure to FMDV (Bayissa et al., 2011; Bronsvoort et al., 2006; Molla et al., 2010). However, the relative high seropositivity of FMDV antibodies in cattle of all age groups as observed in this study, combined with the spatial distribution of the herds over all of the districts in the study area, suggests that there is frequent infection with FMDV in this part of Niger.

In epidemiological settings, such as Niger with the existing livestock management practices, all potential risk factors could contribute to FMD infection. However, the statistical analysis showed that only the herd composition (cattle mixed with small ruminants) was highly significantly associated with FMDV seropositivity in FMD outbreaks. Despite these results, the role of other factors should not be ignored. The role of transhumance in FMD spread has been shown to play an important role elsewhere in sub-Saharan Africa (Rweyemamu et al., 2008). Furthermore, significant buffalo populations exist in West and Central Africa, including the W park (trans-border area shared between Benin, Burkina Faso and Niger). Notably, two districts in the study area (Alambaré and Tamou) are located at the interface zone between domestic animals and wildlife through the national park $\mathrm{W}$ of Niger. To what extent types of FMDV prevalent in domestic ruminants infect wildlife is unknown, and this important pattern of the FMD transmission dynamics remains to be more explained (Ayebazibwe et al., 2010; Di Nardo et al., 2015; Vosloo et al., 2002; Anderson et al., 1993; Fevre et al., 2006). Furthermore, there are important rural livestock markets in the study area (for example Alambaré), where contact between animals increases by absence of any quarantine measure and where subsequently the transmission of FMD virus and other animal diseases is enhanced (Dean et al., 2013; Garland $\&$ de Clercq 2011). It is obvious that the effect of the potential risk factors would be more 
clearly reflected with a comprehensive random sampling in domestic animals as well as in wildlife.

Out of the total analysed epithelium samples ( $n=25)$, only six VP1 sequences were obtained for phylogenetic analysis. This relatively low rate (6/25) of sequence recovery could be explained by several factors such as the insufficient quality of the samples with degradation of the genome, due to a long time of storage of samples - about 10 months - and to poor shipping conditions or, on the other hand, by the lower analytical sensitivity of the sequencing VP1 RTPCRs or primer mismatches. Furthermore, the relative lower quality of epithelium tissue samples could likewise be the reason that one FMDV isolate was recovered among the four samples sent to the WRLFMD. The failure to isolate FMDV from more samples restricted the extent of vaccine matching work that could be performed at the WRLFMD. Further work is urgently required to expand these vaccine-matching studies to more field isolates from the country. Furthermore, these in vitro results would benefit from results of in vivo pilot studies that evaluate the performance of the vaccine in the target host species.

During the last ten years, serotype $O$ field isolates have been characterized in Burkina Faso, Togo, Nigeria, Ghana, Cameroon, Senegal, Mali and Niger. VP1 sequence analysis undertaken in this study indicates that these FMD viruses from Niger are closely related to strains previously isolated in West Africa. These isolates display the closest relationship with the strains from Benin (O/BEN/40/2010 and O/BEN/26/2010), Togo (O/TOG/1/2004 and $\mathrm{O} / \mathrm{TOG} / 1 / 2005)$, and from Ghana (O/Lam/GHA/2012). This close genetic relationship supports the role of cross-border animal movements are a major route by which FMD spreads in the region (Brito et al., 2015; Bronsvoort et al., 2004b; Couacy-Hymann et al., 2006; Di Nardo et al., 2011; Ehizibolo et al., 2014; Fasina et al., 2013; Gorna et al., 2014; Knowles \& Samuel, 2003; WRLFMD, 2016a). In addition to the uncontrolled movement of animals along the border, to our knowledge, countries such as Benin and Togo do not practice mass vaccination against FMD.

In conclusion, the serological and molecular observations of this study urge for continuous surveillance of FMD enabling to monitor the infection status and the spread of FMDV serotypes in livestock as well as in wildlife populations in Niger. It is anticipated that the results of this study despite its limited sampling design will motivate further work to characterise FMDV from field outbreaks in the country where the epidemiological status of the disease is poorly 
understood. In addition, regarding to transboundary animal movements and international animal trade, an integrated control approach at regional or continental level is strongly recommended.

\section{Acknowledgements}

This study was funded by the World Bank project entitled West Africa Agricultural Productivity Program (WAAPP/Niger). The authors are very grateful to herdsmen and farm owners for their hospitality and for allowing samples to be collected from their herds. Particular thanks must be expressed to LABOCEL of Niamey (Niger) for providing the environment for samples storage. The authors also would like to appreciate the efforts of the technical staff of Botswana Vaccine Institute (BVI) and World Reference Laboratory for FMD (WRLFMD), Pirbright, UK, for support with diagnostic analyses. The work of the WRLFMD is supported with funding from the European Union and the views expressed herein can in no way be taken to reflect the official opinion of the European Union. The authors also acknowledge the Central Veterinary of Accra (Ghana) for shipping the samples to BVI.

The authors declare no conflict of interest.

\section{References}

Anderson E. C., Foggin C., Atkinson M., Sorensen K. J., Madekurozva R. L. \& Nqindi J. 1993. The role of wild animals, other than buffalo, in the current epidemiology of foot-and-mouth disease in Zimbabwe. Epidemiol Infect 111: 3, 559-563.

Ayebazibwe C., Mwiine F. N., Tjornehoj K., Balinda S. N., Muwanika V. B., Ademun Okurut A. R., Belsham G. J., Normann P., Siegismund H. R. \& Alexandersen S. 2010. The role of African buffalos (Syncerus caffer) in the maintenance of foot-and-mouth disease in Uganda. BMC Vet Res 6: 54.

Bayissa B., Ayelet G., Kyule M., Jibril Y. \& Gelaye E. 2011. Study on seroprevalence, risk factors, and economic impact of foot-and-mouth disease in Borena pastoral and agro-pastoral system, southern Ethiopia. Trop Anim Health Prod 43: 4, 759-766.

Belsham G. J. 1993. Distinctive features of foot-and-mouth disease virus, a member of the picornavirus family; aspects of virus protein synthesis, protein processing and structure. Prog Biophys Mol Biol 60: $3,241-260$. 
Brito, B. P., Rodriguez, L. L., Hammond, J. M., Pinto, J., \& Perez, A. M. Review of the Global Distribution of Foot-and-Mouth Disease Virus from 2007 to 2014. Transboundary Emer Dis . 2015.

Bronsvoort B. M., Anderson J., Corteyn A., Hamblin P., Kitching R. P., Nfon C., Tanya V. N. \& Morgan K. L. 2006. Geographical and age-stratified distributions of foot-and-mouth disease virus-seropositive and probang-positive cattle herds in the Adamawa province of Cameroon. Vet Rec 159: 10, 299-308

Bronsvoort B. M., Nfon C., Hamman S. M., Tanya V. N., Kitching R. P. \& Morgan K. L. 2004a. Risk factors for herdsman-reported foot-and-mouth disease in the Adamawa Province of Cameroon. Prev Vet Med 66: 1-4, 127-139.

Bronsvoort B. M., Radford A. D., Tanya V. N., Nfon C., Kitching R. P. \& Morgan K. L. 2004b. Molecular epidemiology of foot-and-mouth disease viruses in the Adamawa province of Cameroon. $J$ Clin Microbiol 42: 5, 2186-2196.

Couacy-Hymann E., Aplogan G. L., Sangare O., Compaore Z., Karimu J., Awoueme K. A., Seini A., Martin V. \& Valarcher J. F. 2006. [Retrospective study of foot and mouth disease in West Africa from 1970 to 2003]. Rev Sci Tech 25: 3, 1013-1024.

Dean A. S., Fournie G., Kulo A. E., Boukaya G. A., Schelling E. \& Bonfoh B. 2013. Potential Risk of Regional Disease Spread in West Africa through Cross-Border Cattle Trade. PLoS ONE 8: 10, e75570.

Dhikusooka M. T., Tjornehoj K., Ayebazibwe C., Namatovu A., Ruhweza S., Siegismund H. R., Wekesa S. N., Normann P. \& Belsham G. J. 2015. Foot-and-mouth disease virus serotype SAT 3 in long-horned Ankole calf, Uganda. Emerg Infect Dis 21: 1, 111-114.

Di Nardo A., Knowles N. J. \& Paton D. J. 2011. Combining livestock trade patterns with phylogenetics to help understand the spread of foot and mouth disease in sub-Saharan Africa, the Middle East and Southeast Asia. Rev Sci Tech 30: 1, 63-85.

Di Nardo. A., Libeau G., Chardonnet B., Chardonnet P., Kock R. A., Parekh K., Hamblin P., Li Y., Parida S. \& Sumption K. J. 2015. Serological profile of foot-and-mouth disease in wildlife populations of West and Central Africa with special reference to Syncerus caffer subspecies. Vet Res 46: 77.

Ehizibolo D. O., Perez A. M., Carrillo C., Pauszek S., AlKhamis M., Ajogi I., Umoh J. U., Kazeem H. M., Ehizibolo P. O., Fabian A., Berninger M., Moran K., Rodriguez L. L. \& Metwally S. A. 2014. 
Epidemiological analysis, serological prevalence and genotypic analysis of foot-and-mouth disease in Nigeria 2008-2009. Transbound Emerg Dis 61: 6, 500-510.

Fasina F. O., Connell D. R., Talabi O. A., Lazarus D. D., Adeleke G. A., Olusanya T. P. \& Hernandez J. A. 2013. Foot-and-mouth disease virus strains and examination of exposure factors associated with seropositivity of cattle herds in Nigeria during 2007-2009. Prev Vet Med 109: 3-4, 334-342.

Fevre E. M., Bronsvoort B. M. D. C., Hamilton K. A. \& Cleaveland S. 2006. Animal movements and the spread of infectious diseases. Trends Microbiol 14: 3, 125-131.

Garland A. J. \& de C. K. 2011. Cattle, sheep and pigs vaccinated against foot and mouth disease: does trade in these animals and their products present a risk of transmitting the disease? Rev Sci Tech 30: 1, 189-206.

Gleeson L. J. 2002. A review of the status of foot and mouth disease in South-East Asia and approaches to control and eradication. Rev Sci Tech 21: 3, 465-475.

Gorna K., Houndje E., Romey A., Relmy A., Blaise-Boisseau S., Kpodekon M., Saegerman C., Moutou F., Zientara S. \& Bakkali K. L. 2014. First isolation and molecular characterization of foot-and-mouth disease virus in Benin. Vet Microbiol 171: 1-2, 175-181.

Hall. BioEdit. A user friendly biological sequence alignment editor and analysis program for windows 98/98 NT. Nucleic Acids Symposium Series. 41, 95-98. 1999.

Hamblin C., Barnett I. T. \& Crowther J. R. 1986. A new enzyme-linked immunosorbent assay (ELISA) for the detection of antibodies against foot-and-mouth disease virus. II. Application. J Immunol Methods 93: $1,123-129$.

Hedger RS, Barnett BA, Gradwell DV, Travassos Dias P. Serological tests for foot-and-mouth disease in bovine serum samples. Problems of interpretation. Rev. Sci. Tech. $1982 ; 1$ :387-393.

Hosmer D. W. \& Lemeshow S. 2000. Logistic Regression for Matched Case-Control Studies. In: Applied Logistic Regression. John Wiley \& Sons, Inc.,.223 - 259.

Jackson A. L., O'Neill H., Maree F., Blignaut B., Carrillo C., Rodriguez L. \& Haydon D. T. 2007. Mosaic structure of foot-and-mouth disease virus genomes. J Gen Virol 88: Pt 2, 487-492. 
Kasambula L., Belsham G. J., Siegismund H. R., Muwanika V. B., Ademun-Okurut A. R. \& Masembe C. 2012. Serotype identification and VP1 coding sequence analysis of foot-and-mouth disease viruses from outbreaks in eastern and northern Uganda in 2008/9. Transbound Emerg Dis 59: 4, 323-330.

Kitching R. P., Knowles N. J., Samuel A. R. \& Donaldson A. I. 1989. Development of foot-and-mouth disease virus strain characterisation--a review. Trop Anim Health Prod 21: 3, 153-166.

Knowles N. J. \& Samuel A. R. 2003. Molecular epidemiology of foot-and-mouth disease virus. Virus $\operatorname{Res} 91: 1,65-80$.

Knowles, N. J., Wadsworth, J., Bachanek-Bankowska, K. \& King, D. P. 2016. VP1 sequencing protocol for foot and mouth disease virus molecular epidemiology. Rev Sci Tech Off Int Epiz 35 (3): in press.

La Rovere R., Hiernaux P., Van Keulen H., Schiere J. B. \& Szonyi J. A. 2005. Co-evolutionary scenarios of intensification and privatization of resource use in rural communities of south-western Niger. Agricultural Systems 83: 3, 251-276.

Ludi A., Ahmed Z., Pomeroy L. W., Pauszek S. J., Smoliga G. R., Moritz M., Dickmu S., Abdoulkadiri S., Arzt J., Garabed R. \& Rodriguez L. L. 2016. Serotype Diversity of Foot-and-Mouth-Disease Virus in Livestock without History of Vaccination in the Far North Region of Cameroon. Transbound Emerg Dis 63: 1, e27-e38.

Molla B., Ayelet G., Asfaw Y., Jibril Y., Ganga G. \& Gelaye E. 2010. Epidemiological study on footand-mouth disease in cattle: seroprevalence and risk factor assessment in South Omo zone, southwestern Ethiopia. Transbound Emerg Dis 57: 5, 340-347.

Mwiine F. N., Ayebazibwe C., Olaho-Mukani W., Alexandersen S., Balinda S. N., Masembe C., Okurut A. R., Christensen L. S., Sorensen K. J. \& Tjornehoj K. 2010. Serotype specificity of antibodies against foot-and-mouth disease virus in cattle in selected districts in Uganda. Transbound Emerg Dis 57: 5, 365-374.

Namatovu A., Tjornehoj K., Belsham G. J., Dhikusooka M. T., Wekesa S. N., Muwanika V. B., Siegismund H. R. \& Ayebazibwe C. 2015. Characterization of foot-and-mouth disease viruses (FMDVs) from Ugandan cattle outbreaks during 2012-2013: evidence for circulation of multiple serotypes. PLoS One 10: 2, e0114811.

OIE 2012. Manual of Diagnostic Tests and Vaccines for Terrestrial Animals: Foot and mouth disease (infection with foot and mouth disease virus) (Version adopted in May 2012). (Chapter 2.1.8). Available 
at: $\quad$ http://www.oie.int/fileadmin/Home/eng/Health_standards/tahm/2.01.08_FMD.pdf. (accessed 20.10.16).

Olabode O. H., Kazeem H. M. \& Raji M. A. 2014. Diagnosis of bovine foot and mouth disease virus by real-time polymerase chain reaction and nucleotide sequencing from outbreak herd samples in Ilesha Baruba, Kwara state, Nigeria. Vet World 7: 10, 868-875.

Pagot J. 1948. La fièvre aphteuse au Niger. Revue d'élevage et de médecine vétérinaire des pays tropicaux 2 : 118-119.

Paton D. J., Valarcher J. F., Bergmann I., Matlho O. G., Zakharov V. M., Palma E. L. \& Thomson G. R. 2005. Selection of foot and mouth disease vaccine strains--a review. Rev Sci Tech 24: 3, 981-993.

Petrie A. a. P. W. 2006. Additional Techniques in Statistics for Veterinary and Animal Science.Blackwell Science O, editor. Blackwell Science, Oxford,.UK, 191 - 211.

Preux, P. M., P. Odermatt, A. Perna, B. Marin, and A. Vergnenegre 2005. Qu'est-ce qu'une régression logistique? Rev Mal Respir 22: 159-162

Rweyemamu M. M., Pay T. W. \& Parker M. J. 1976. Serological differentiation of foot-and-mouth disease virus strains in relation to selection of suitable vaccine viruses. Dev Biol Stand 35: 205-4.

Rweyemamu M., Roeder P., Mackay D., Sumption K., Brownlie J., Leforban Y., Valarcher J. F., Knowles N. J. \& Saraiva V. 2008. Epidemiological patterns of foot-and-mouth disease worldwide. Transbound Emerg Dis 55: 1, 57-72.

Samuel A. R. \& Knowles N. J. 2001. Foot-and-mouth disease type O viruses exhibit genetically and geographically distinct evolutionary lineages (topotypes). J Gen Virol 82: Pt 3, 609-621.

Sangare O., Bastos A. D. S., Venter E. H. \& Vosloo W. 2003. Retrospective genetic analysis of SAT-1 type foot-and-mouth disease outbreaks in West Africa (1975-1981). Vet Microbiol 93 : 4, 279-289.

Sangare O., Bastos A. D., Marquardt O., Venter E. H., Vosloo W. \& Thomson G. R. 2001. Molecular epidemiology of serotype $\mathrm{O}$ foot-and-mouth disease virus with emphasis on West and South Africa. Virus Genes 22: 3, 345-351. 
Sangare O., Bastos A. D., Venter E. H. \& Vosloo W. 2004a. A first molecular epidemiological study of SAT-2 type foot-and-mouth disease viruses in West Africa. Epidemiol Infect 132: 3, 525-532.

Sangare O., Dungu B. \& Bastos A. D. 2004b. Foot and mouth disease in Mali : the current situation and proposed control strategies. Rev Sci Tech 23: 3, 863-872.

Tamura K., Stecher G., Peterson D., Filipski A. \& Kumar S. 2013. MEGA6: Molecular Evolutionary Genetics Analysis version 6.0. Mol Biol Evol 30: 12, 2725-2729.

Tekleghiorghis T., Moormann R. J. M., Weerdmeester K. \& Dekker A. 2016. Foot-and-mouth Disease Transmission in Africa: Implications for Control, a Review. Transboundary Emer Dis 63: 2, 136-151.

Thompson J. D., Higgins D. G. \& Gibson T. J. 1994. CLUSTAL W: improving the sensitivity of progressive multiple sequence alignment through sequence weighting, position-specific gap penalties and weight matrix choice. Nucleic Acids Res 22: 22, 4673-4680.

Turner M. D. \& Williams T. O. 2002. Livestock market dynamics and local vulnerabilities in the Sahel. World Development 30: 4, 683-705.

Ularamu H. G., Ibu J. O., Wood B. A., Abenga J. N., Lazarus D. D., Wungak Y. S., Knowles N. J., Wadsworth J., Mioulet V., King D. P., Shamaki D. \& Adah M. I. 2016. Characterization of Foot-andMouth Disease Viruses Collected in Nigeria Between 2007 and 2014: Evidence for Epidemiological Links Between West and East Africa. Transbound Emerg Dis.

Vosloo W., Boshoff K., Dwarka R. \& Bastos A. 2002. The possible role that buffalo played in the recent outbreaks of foot-and-mouth disease in South Africa. Ann N Y Acad Sci 969: 187-190.

Vosloo W., Bastos A. D., Sangare O., Hargreaves S. K. \& Thomson G. R. 2002. Review of the status and control of foot and mouth disease in sub-Saharan Africa. Rev Sci Tech 21: 3, 437-449. 


\section{Table and figure captions}

Table 1: Overview of the sampling strategy

Legend: ${ }^{a}$ : Epithelium samples collected from sick animals with existing oral and foot lesions,

${ }^{b}$ : sera collected from all examined animals during the herd visit, including those on which epithelium samples were collected. $\mathrm{i}+\mathrm{j}=$ total number of sampled animals during the herd visit that correspond to the total number of sera.

Table 2: NSP ELISA positive animals by age class

Legend: Sampled cattle were classified into 4 age group, this table shows the seroprevalence of animals of each age class, 70\% represent the overall seroprevalence yielded by NSP ELISA.

Table 3: Potential risk factors associated with FMDV seropositivity based on a univariate logistic regression model

Legend: * P-value less than 0.05, OR: Odds Ratio, CI: Confidence Interval.

Table 4: Final model of risk factors associated with FMDV seropositivity based on a multivariate logistic regression model

Legend: * P-value less than 0.05, OR: Odds Ratio, CI: Confidence Interval.

Table 5: Diagnostic results on epithelium samples collected in Niger in 2014 and the GenBank accession number of VP1 sequences

Legend: P: passage; FMDV-GD: FMDV genome detected; Age class: 0: $\leq 2$ years; $1:>2$ and $\leq 3$ years; 2: $>2$ and $\leq 4$ years; 3: $>4$ years. Epithelium tissues $(n=25)$ were obtained from clinical FMD cattle originating from seven districts of southwestern of Niger. This table indicates the positive diagnostic (virus isolation, Ag-ELISA and PCR) results with high quality sequences $(\mathrm{n}=6)$. These positives samples were from the following districts: Gaya (GY), Makalondi (MK) and Kollo (KL).

Table 6: ' $r 1$ ' values obtained between FMDV serotype $O$ field isolates and vaccine strains Legend: An ' $r$ ' value greater than 0.3 indicates the existence of close antigenic relationship between the vaccine strain and the field isolate.

Figure 1: Geographical locations of FMD outbreaks described in this study

Legend: Administrative regions: 1: Agadez, 2: Diffa, 3: Dosso, 4: Maradi, 5: Tahoua, 6: Tillabery, 7: Zinder and Niamey (capital city). Study area (Eight sampling districts described in this study): Niamey, Kollo, MK: Makalondi, Gaya (that covers administratively the district of Tanda, Dole) and Tamou (covering administratively Alambaré). 
Figure 2: Liquid Phase Blocking ELISA results based on geographical locations of FMD outbreaks

Legend: 4e Arrd is one the district of Niamey called the fourth Arrondissement. Sera $(n=227)$ were collected in 8 districts of southwestern of the country. LPBE test was performed on NSP ELISA positive samples $(\mathrm{n}=158)$.

Figure 3: Prevalence of single or multiple FMDV serotypes detected in LPBE Legend: The LPB ELISA test was performed on NSP ELISA positive samples $(n=158)$. The total sera represent 227 samples from both subclinical and clinical cattle. Neg: Negative, A: single response to serotype A, O: single response to serotype O, SAT1: single response to serotype SAT1, SAT2: single response to serotype SAT2, the remaining are multiple responses to FMDV serotypes (see Appendix 2).

Figure 4: Midpoint-rooted Neighbor-joining tree showing the relationship between the VP1 sequences of serotype $\mathrm{O}$ isolated in Niger

Legend: WA=West Africa; ME-SA= Middle-Est and South Africa. 
Table 1: Overview of the sampling strategy

\begin{tabular}{|c|c|c|c|c|c|}
\hline $\begin{array}{l}\text { Sampling } \\
\text { site }\end{array}$ & $\begin{array}{l}\text { Number of herds } \\
\text { visited }\end{array}$ & $\begin{array}{l}\text { Number of } \\
\text { sick animals } i\end{array}$ & $\begin{array}{l}\text { Number of apparently } \\
\text { healthy animals }{ }^{j}\end{array}$ & \multicolumn{2}{|c|}{$\begin{array}{l}\text { Number of Samples } \\
\text { collected }\end{array}$} \\
\hline & & & & Epithelium $^{\mathbf{a}}$ & Serum $^{\mathbf{b}}$ \\
\hline Makalondi & 6 & 32 & 13 & 7 & 45 \\
\hline Gaya & 1 & 4 & 3 & 2 & 7 \\
\hline Dolé & 4 & 8 & 12 & 1 & 20 \\
\hline Tanda & 2 & 9 & 9 & 1 & 18 \\
\hline Alambaré & 2 & 11 & 8 & 5 & 19 \\
\hline Tamou & 3 & 2 & 10 & 2 & 12 \\
\hline Kollo & 5 & 26 & 29 & 7 & 55 \\
\hline $\begin{array}{l}\text { 4e Arrd } \\
\text { (Niamey) }\end{array}$ & 5 & 27 & 24 & 0 & 51 \\
\hline Total & 28 & 119 & 108 & 25 & 227 \\
\hline
\end{tabular}

Legend: ${ }^{\text {a }}$ : Epithelium samples collected from sick animals with existing oral and foot lesions, ${ }^{\mathrm{b}}$ : sera collected from all examined animals during the herd visit, including those on which epithelium samples were collected. $\mathrm{i}+\mathrm{j}=$ total number of sampled animals during the herd visit that correspond to the total number of sera. 
Table 2: NSP ELISA positive animals by age class

\begin{tabular}{llll}
\hline Age category & Number of tested animal & $\begin{array}{l}\text { Number of NSP ELISA } \\
\text { positive }\end{array}$ & $\begin{array}{l}\text { Seroprevalence } \\
(\%)\end{array}$ \\
\hline$\leq 2$ years & 74 & 52 & 70 \\
$>2$ and $\leq 3$ years & 58 & 36 & 62 \\
$>3$ and $\geq 4$ years & 47 & 39 & 83 \\
$>4$ years & 48 & 31 & 65 \\
Total & $\mathbf{2 2 7}$ & $\mathbf{1 5 8}$ & $\mathbf{7 0}$
\end{tabular}

Legend: Sampled cattle were classified into 4 age group, this table shows the seroprevalence of animals of each age class, $70 \%$ represent the overall seroprevalence yielded by NSP ELISA. 
Table 3: Potential risk factors associated with FMDV seropositivity based on a univariate logistic regression model

\begin{tabular}{|c|c|c|c|c|}
\hline Variable & Modality & OR & $95 \% \mathrm{CI}$ & $P$-value \\
\hline \multirow[t]{8}{*}{ Commune } & 4th Arrondissement & Ref. & - & - \\
\hline & Alambaré & 0.94 & $\begin{array}{l}0.31- \\
2.79\end{array}$ & 0.90 \\
\hline & Dolé & 2.18 & $\begin{array}{l}0.63- \\
7.52\end{array}$ & 0.22 \\
\hline & Gaya & 0.41 & $\begin{array}{l}0.08- \\
2.03\end{array}$ & 0.28 \\
\hline & Kolo & 1.60 & $\begin{array}{l}0.69- \\
3.68\end{array}$ & 0.27 \\
\hline & Makalondi & 1.21 & $\begin{array}{l}0.51- \\
2.84\end{array}$ & 0.67 \\
\hline & Tamou & 6.00 & $\begin{array}{l}0.72- \\
50.30\end{array}$ & 0.10 \\
\hline & Tanda & 0.86 & $\begin{array}{l}0.28- \\
2.60\end{array}$ & 0.79 \\
\hline \multirow[t]{2}{*}{ Herd type } & $\begin{array}{l}\text { Nomadism or } \\
\text { transhumance }\end{array}$ & Ref. & - & - \\
\hline & Sedentary & 0.94 & $\begin{array}{l}0.44- \\
1.98\end{array}$ & 0.86 \\
\hline Herd size (continue variable) & Size & 1.001 .827 & $\begin{array}{l}0.99- \\
1.01\end{array}$ & 0.48 \\
\hline \multirow[t]{3}{*}{ Herd composition } & Only cattle & Ref. & - & - \\
\hline & $\begin{array}{l}\text { Cattle and small } \\
\text { ruminants }\end{array}$ & 3.60 & $\begin{array}{l}1.58- \\
8.22\end{array}$ & $0.002 *$ \\
\hline & Other & 1.60 & $\begin{array}{l}0.78- \\
3.27\end{array}$ & 0.20 \\
\hline \multirow[t]{2}{*}{ Contact with wildlife } & Rare & Ref. & - & - \\
\hline & No & 0.92 & $\begin{array}{l}0.49- \\
1.74\end{array}$ & 0.80 \\
\hline Transhumance destination & Inside the country & Ref. & - & - \\
\hline
\end{tabular}




\begin{tabular}{|c|c|c|c|c|}
\hline & Outside the country & 0.71 & $\begin{array}{l}0.14- \\
3.75\end{array}$ & 0.69 \\
\hline & $\begin{array}{l}\text { Inside and outside the } \\
\text { country }\end{array}$ & 0.87 & $\begin{array}{l}0.17- \\
4.56\end{array}$ & 0.87 \\
\hline & No & 0.56 & $\begin{array}{l}0.10- \\
3.36\end{array}$ & 0.53 \\
\hline \multirow{2}{*}{$\begin{array}{l}\text { Detection of FMD cases after the } \\
\text { transhumance }\end{array}$} & Yes & Ref. & - & - \\
\hline & No & 0.72 & $\begin{array}{l}0.37- \\
1.40\end{array}$ & 0.33 \\
\hline \multirow[t]{2}{*}{ Gender } & Male & Ref. & - & - \\
\hline & Female & 0.97 & $\begin{array}{l}0.55- \\
1.74\end{array}$ & 0.94 \\
\hline \multirow[t]{4}{*}{ Age } & $\leq 2$ years & Ref. & - & - \\
\hline & Between 2 and 3 years & 0.69 & $\begin{array}{l}0.33- \\
1.43\end{array}$ & 0.32 \\
\hline & Between 3 and 4 years & 2.06 & $\begin{array}{l}0.83- \\
5.12\end{array}$ & 0.12 \\
\hline & $\geq 4$ years & 0.77 & $\begin{array}{l}0.36- \\
1.67\end{array}$ & 0.51 \\
\hline \multirow[t]{2}{*}{ Animal origin } & Birth inside the herd & Ref. & - & - \\
\hline & Birth outside the herd & 0.85 & $\begin{array}{l}0.39- \\
1.87\end{array}$ & 0.69 \\
\hline \multirow[t]{2}{*}{ Clinical signs } & Presence & Ref. & - & - \\
\hline & Absence & 1.17 & $\begin{array}{l}0.66- \\
2.06\end{array}$ & 0.60 \\
\hline \multirow[t]{2}{*}{ Lesions } & Presence & Ref. & - & - \\
\hline & Absence & 1.24 & $\begin{array}{l}0.64- \\
2.39\end{array}$ & 0.52 \\
\hline
\end{tabular}

Legend: * P-value less than 0.05, OR: Odds Ratio, CI: Confidence Interval. 
Table 4: Final model of risk factors associated with FMDV seropositivity based on a multivariate logistic regression model

\begin{tabular}{|c|c|c|c|c|}
\hline Variable & Modality & OR & $95 \% \mathrm{CI}$ & $P$-value \\
\hline \multirow[t]{9}{*}{ Commune } & 4 th & Ref. & - & - \\
\hline & Arrondissement & & & \\
\hline & Alambaré & 0.79 & $(0.24-2.54)$ & 0.70 \\
\hline & Dolé & 2.02 & $(0.51-8.07)$ & 0.32 \\
\hline & Gaya & 1.09 & $(0.15-7.80)$ & 0.93 \\
\hline & Kolo & 1.49 & $(0.47-4.77)$ & 0.50 \\
\hline & Makalondi & 1.96 & $(0.57-6.72)$ & 0.29 \\
\hline & Tamou & 7.04 & $(0.70-70.97)$ & 0.10 \\
\hline & Tanda & 0.86 & $(0.28-2.60)$ & 0.79 \\
\hline \multirow[t]{3}{*}{ Herd composition } & Only cattle & Ref. & - & - \\
\hline & $\begin{array}{l}\text { Cattle and } \\
\text { small } \\
\text { ruminants }\end{array}$ & 3.99 & $(1.47-10.82)$ & $0.006^{*}$ \\
\hline & Other & 2.66 & $(0.85-8.34)$ & 0.10 \\
\hline
\end{tabular}


1 Table 5: Diagnostic results on epithelium samples collected in Niger in 2014 and the

2 GenBank accession numbers of VP1 sequences

\begin{tabular}{|c|c|c|c|c|c|c|c|c|}
\hline $\begin{array}{l}\text { Samp } \\
\text { le ID }\end{array}$ & $\begin{array}{l}\text { BVI } \\
\text { code }\end{array}$ & $\begin{array}{l}\text { WRLF } \\
\text { MD } \\
\text { code }\end{array}$ & $\begin{array}{l}\text { Outbreak } \\
\text { Location }\end{array}$ & $\begin{array}{l}\text { Ani } \\
\text { mal } \\
\text { age } \\
\text { class }\end{array}$ & $\begin{array}{l}\text { Cell } \\
\text { Cultu } \\
\text { re } \\
\text { passa } \\
\text { ge }\end{array}$ & $\begin{array}{l}\text { Serotypi } \\
\text { ng by } \\
\text { Ag- } \\
\text { ELISA }\end{array}$ & PCR & $\begin{array}{l}\text { GenBa } \\
\text { nk } \\
\text { accessi } \\
\text { on No. }\end{array}$ \\
\hline GY7 & $\begin{array}{l}\text { NGR/11/ } \\
2015\end{array}$ & & Gaya & 1 & $3^{\text {rd }} \mathrm{P}$ & $\mathrm{O}$ & $\begin{array}{l}\text { FMDV- } \\
\text { GD }\end{array}$ & $\frac{\text { KX424 }}{\underline{677}}$ \\
\hline MK7 & $\begin{array}{l}\text { NGR/15/ } \\
2015\end{array}$ & & $\begin{array}{l}\text { Makalondi } \\
\text { Makalondi }\end{array}$ & 0 & $1^{\text {st }} \mathrm{P}$ & $\mathrm{O}$ & $\begin{array}{l}\text { FMDV- } \\
\text { GD }\end{array}$ & $\frac{\mathrm{KX} 424}{\underline{678}}$ \\
\hline MK17 & $\begin{array}{l}\text { NGR/16/ } \\
2015\end{array}$ & & & 0 & $2^{\text {nd }} \mathrm{P}$ & $\mathrm{O}$ & $\begin{array}{l}\text { FMDV- } \\
\text { GD }\end{array}$ & $\frac{\mathrm{KX} 424}{\underline{679}}$ \\
\hline KL2 & $\begin{array}{l}\text { NGR/20/ } \\
2015\end{array}$ & $\begin{array}{l}\text { NGR/4/ } \\
2015\end{array}$ & $\begin{array}{l}\text { Kollo } \\
\text { Kollo }\end{array}$ & 0 & $1^{\text {st }} \mathrm{P}$ & $\mathrm{O}$ & $\begin{array}{l}\text { FMDV- } \\
\text { GD }\end{array}$ & $\frac{\mathrm{KX} 424}{\underline{680}}$ \\
\hline KL44 & $\begin{array}{l}\text { NGR/21/ } \\
2015\end{array}$ & & Kollo & 2 & $1^{\text {st }} \mathrm{P}$ & $\mathrm{O}$ & $\begin{array}{l}\text { FMDV- } \\
\text { GD }\end{array}$ & $\frac{\mathrm{KX} 424}{\underline{681}}$ \\
\hline KL3 & $\begin{array}{l}\text { NGR/24/ } \\
2015\end{array}$ & & & 3 & $1^{\mathrm{st}} \mathrm{P}$ & $\mathrm{O}$ & $\begin{array}{l}\text { FMDV- } \\
\text { GD }\end{array}$ & $\frac{\mathrm{KX} 424}{\underline{682}}$ \\
\hline
\end{tabular}

Legend: P: passage; FMDV-GD: FMDV genome detected; Age class: $0: \leq 2$ years; $1:>2$ and $\leq 3$ years; 2: $>2$ and $\leq 4$ years; $3:>4$ years. Epithelium tissues $(n=25)$ were obtained from clinical FMD cattle originating from seven districts of southwestern of Niger. This table indicates the positive diagnostic (virus isolation, Ag-ELISA and PCR) results with high quality sequences $(\mathrm{n}=6)$. These positives samples were from the following districts: Gaya (GY), Makalondi (MK) and Kollo (KL). 
12 Table 6: ' $\mathrm{rl}$ ' values obtained between FMDV serotype $\mathrm{O}$ field isolates and vaccine strains

\section{D-VNT r1 value}

\begin{tabular}{c}
\hline \multicolumn{2}{c}{ Vaccines strains } \\
O3039
\end{tabular}

Field isolate (O/NGR/4/2015) $\quad 0.63 \quad 0.36 \quad 0.6$

13 Legend: An ' $r_{1}$ ' value greater than 0.3 indicates the existence of close antigenic relationship 14 between the vaccine strain and the field isolate.

15

16

17 
Fig. 1

19

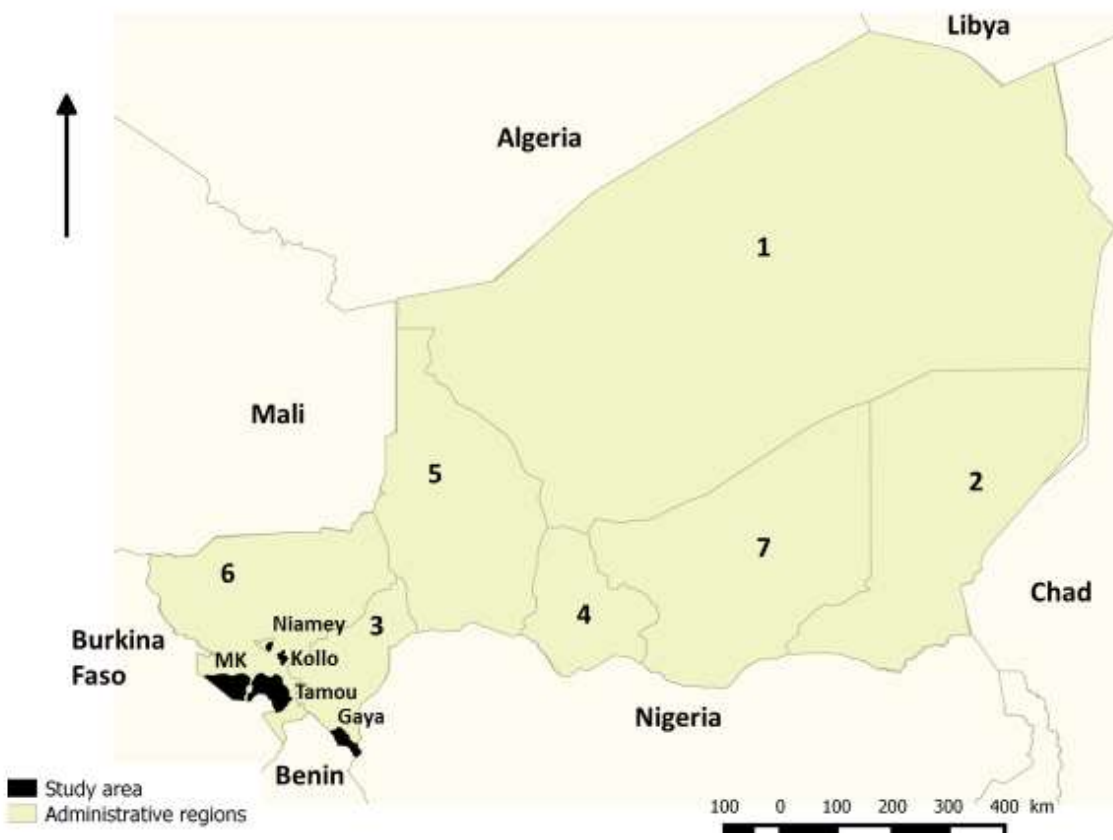

20 
Fig. 2

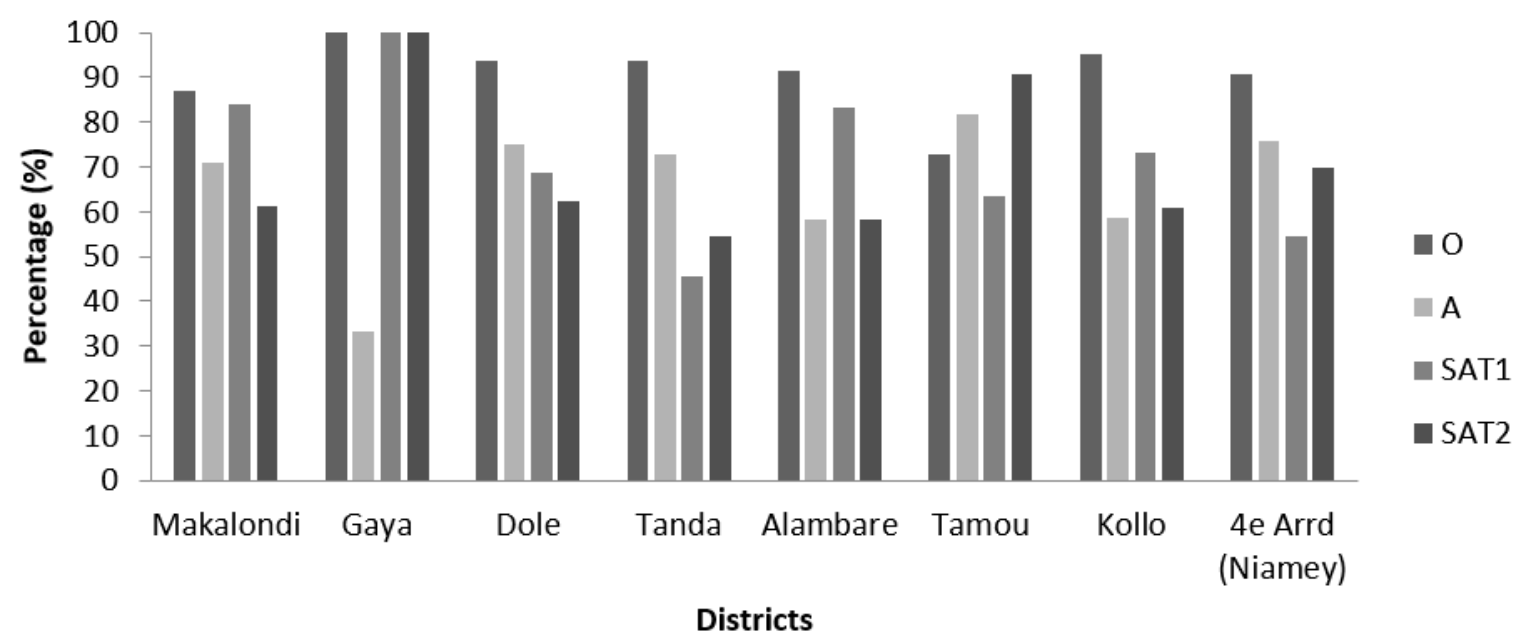

22 
Fig. 3

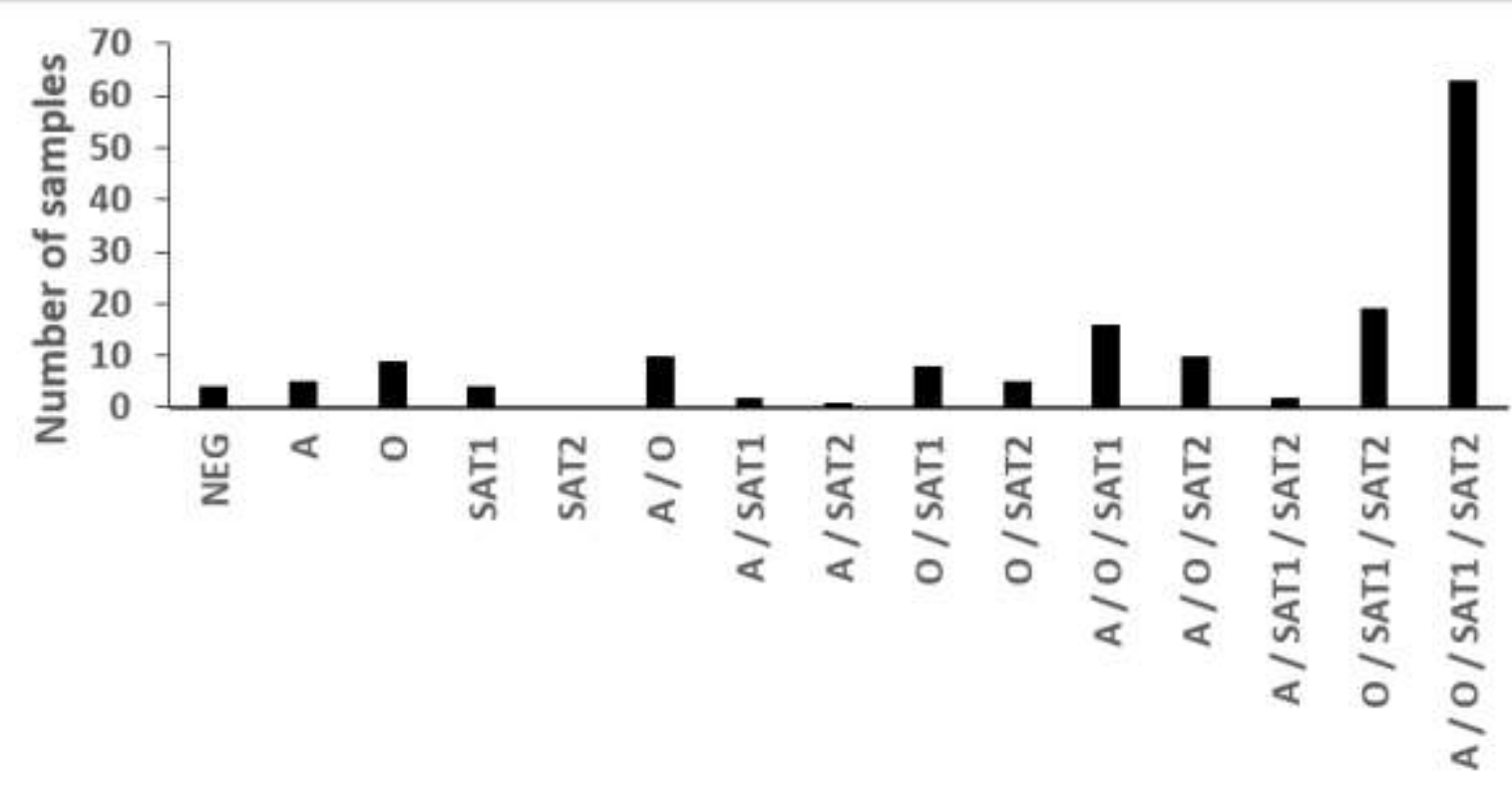

Serotypes

25

26 
$27 \quad$ Fig. 4 


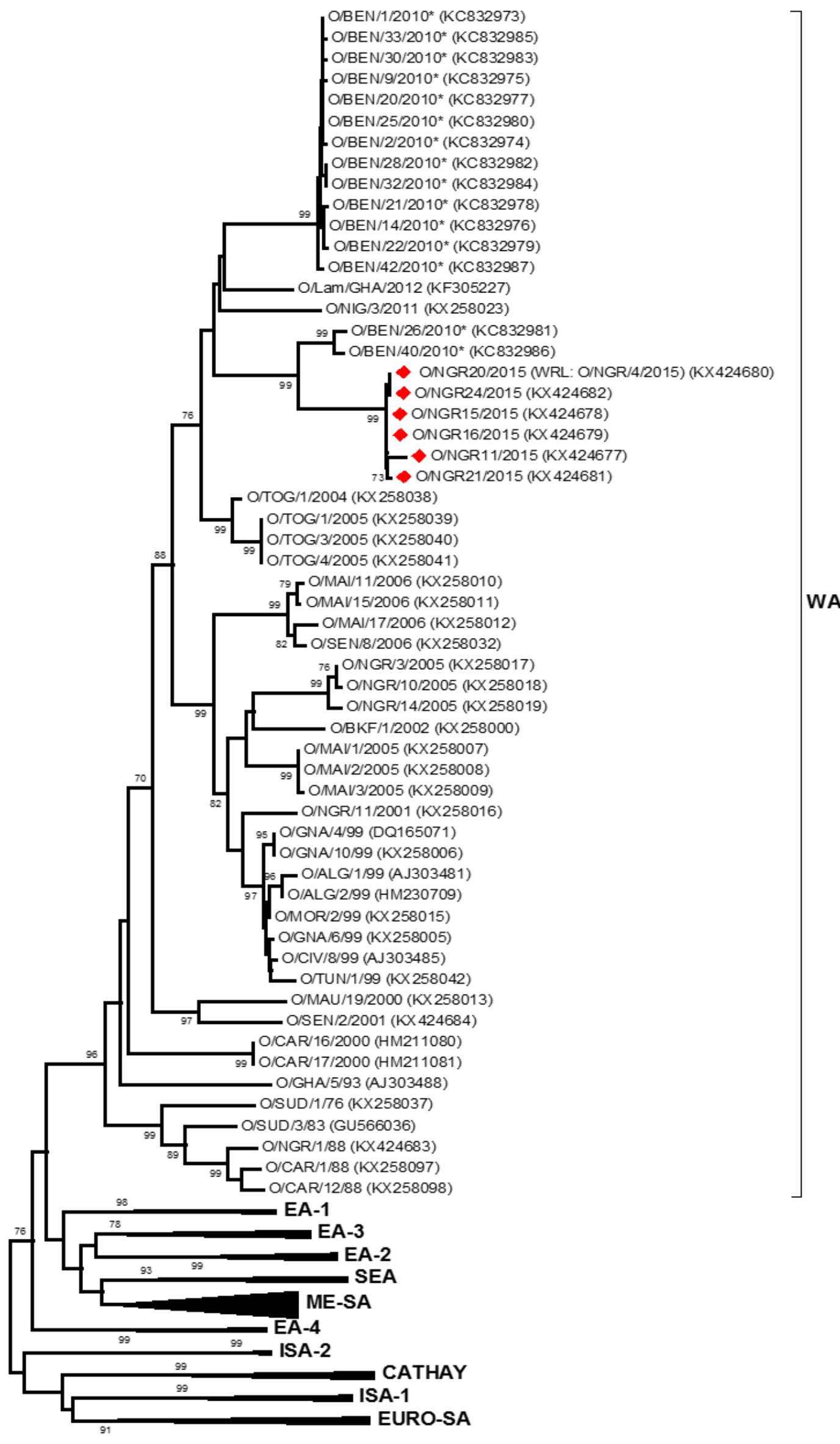




\section{Background information}

- Region:

Department:

Commune:

Locality:....

- Geographic coordinates: Longitude: Latitude:

- Owner's name:

Animal identification

- Sexe: Male $\square \quad$ Female

- Age

\begin{tabular}{|l|l|l|l|}
\hline \multicolumn{3}{|c|}{ Age category } \\
\hline$<2$ years & {$[2-3$ years[ } & {$[3-4$ years [} & $>4$ years \\
\hline & & & \\
\hline
\end{tabular}

44

45

- Animal origin

Born in the herd: Yes No

Introduced from other area: Yes $\square$ No

- Herd composition

Herd of only cattle: Yes $\square$ No

Herd of cattle, sheep and goat: Yes $\quad \square$ No

Herd of cattle, sheep, goat and other domestics animals: Yes $\square$ No

- Grazing habit of livestock

Grazing all neighbors livestock together as one herd: Yes

Grazing house hold herd separetly: Yes $\quad \square$ No

Mixing at watering points: Yes $\square$ No $\square$ 
Herd not mixed at watering / watered at different site: Yes

59

60

64

65

66

67

68

69

70

71

72

73

74

75

76

77

78

79

80

81

82

83

84

85
- Contact history to wildlife

Herd have contact to wild animals usually: $\quad$ Yes $\square \quad$ No $\square$

Have contact only rarely: Yes $\square$ No $\square$

Have no contact at all: Yes $\square$ No $\square$
64

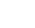

6

70

$\bullet \quad$ Do you usually conduct your herd to transhumance:
Yes $\square \quad$ No $\square$

If so, what is the main destination of transhumance? (1) country (Which one?)

\section{(1)} Yes $\square \quad$ No $\square$

82

83

- Clinical signs, type of lesions observed and samples taken

$\square$ Neighboring region $\square$ Neighboring district $\square$ Some where in the country (Niger) $\square$ Neighboring

- After returning from transhumance in your district, have you had some FMD cases? 


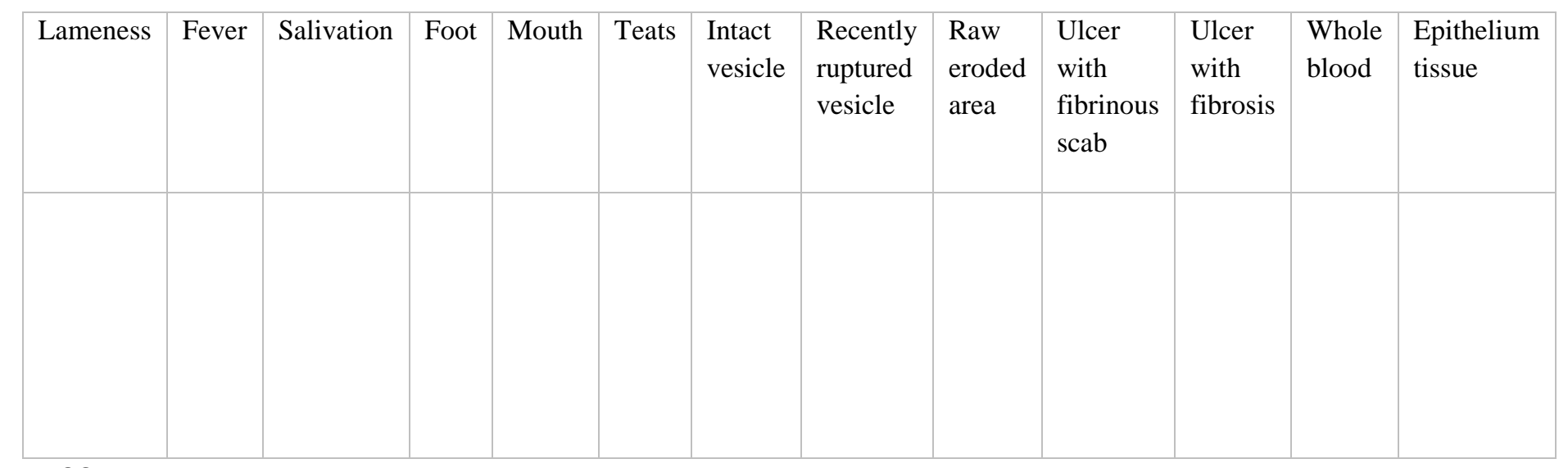

86

87

88

89 
91 Appendix 2: Individual serological response to NSP ELISA and LPBE tests

\begin{tabular}{|c|c|c|c|c|c|c|}
\hline Sample ID & PI (NSP) & & & LPB EL & SA titr: & tion results \\
\hline & & $\bar{A}$ & $\mathbf{O}$ & SAT1 & SAT2 & Result interpretation \\
\hline MK1 & 67 & 1.54 & 1.93 & 1.84 & 1.94 & OSAT1SAT2 \\
\hline MK2 & 81 & 1.40 & 1.92 & 1.69 & 1.95 & OSAT1SAT2 \\
\hline MK3 & 91 & 1.76 & 1.93 & 1.78 & 1.94 & AOSAT1SAT2 \\
\hline MK4 & 95 & 1.93 & 1.92 & 1.94 & 1.95 & AOSAT1SAT2 \\
\hline MK5 & 94 & 1.78 & 1.91 & 1.85 & 1.94 & AOSAT1SAT2 \\
\hline MK7 & 91 & 1.94 & 1.92 & 1.62 & 1.89 & AOSAT1SAT2 \\
\hline MK8 & 87 & 1.74 & 1.90 & 1.71 & 1.95 & AOSAT1SAT2 \\
\hline MK9 & 72 & 1.77 & 1.90 & 1.85 & 1.56 & AOSAT1 \\
\hline MK10 & 85 & 1.88 & 1.93 & 1.93 & 1.95 & AOSAT1SAT2 \\
\hline MK11 & 95 & 1.85 & 1.87 & 1.80 & 1.94 & AOSAT1SAT2 \\
\hline MK12 & 91 & 1.93 & 1.90 & 1.88 & 1.93 & AOSAT1SAT2 \\
\hline MK13 & 87 & 1.71 & 1.93 & 1.81 & 1.94 & AOSAT1SAT2 \\
\hline MK15 & 95 & 1.91 & 1.93 & 1.87 & 1.84 & AOSAT1SAT2 \\
\hline MK16 & 65 & 1.41 & 1.92 & 1.77 & 1.92 & OSAT1SAT2 \\
\hline MK24 & 83 & 1.76 & 1.79 & 1.75 & 1.73 & AOSAT1SAT2 \\
\hline MK25 & 91 & 1.51 & 0.93 & 1.84 & 1.28 & SAT1 \\
\hline MK26 & 65 & 1.22 & 1.56 & 1.43 & 1.57 & Negative \\
\hline MK27 & 97 & 1.93 & 0.82 & 1.87 & 1.17 & ASAT1 \\
\hline MK28 & 90 & 1.93 & 1.93 & 1.95 & 1.52 & AOSAT1 \\
\hline MK30 & 62 & 1.94 & 1.92 & 1.84 & 1.58 & AOSAT1 \\
\hline MK31 & 79 & 1.93 & 1.48 & 1.90 & 1.46 & ASAT1 \\
\hline MK32 & 96 & 1.94 & 1.93 & 1.86 & 1.95 & AOSAT1SAT2 \\
\hline
\end{tabular}




\begin{tabular}{|c|c|c|c|c|c|c|}
\hline MK33 & 56 & 1.82 & 1.95 & 1.91 & 1.91 & AOSAT1SAT2 \\
\hline MK35 & 79 & 1.90 & 1.88 & 1.91 & 1.32 & AOSAT1 \\
\hline MK36 & 97 & 1.94 & 1.93 & 1.94 & 1.95 & AOSAT1SAT2 \\
\hline MK38 & 92 & 1.90 & 1.87 & 1.78 & 1.92 & AOSAT1SAT2 \\
\hline MK39 & 72 & 1.74 & 1.84 & 1.78 & 1.04 & AOSAT1 \\
\hline MK40 & 78 & 1.87 & 1.89 & 1.87 & 1.86 & AOSAT1SAT2 \\
\hline MK42 & 80 & 0.99 & 1.49 & 1.71 & 0.51 & SAT1 \\
\hline MK44 & 73 & 1.58 & 1.92 & 1.75 & 1.93 & OSAT1SAT2 \\
\hline MK45 & 56 & 1.32 & 1.90 & 1.91 & 1.45 & OSAT1 \\
\hline GY2 & 61 & 1.49 & 1.92 & 1.79 & 1.73 & OSAT1SAT2 \\
\hline GY3 & 95 & 1.56 & 1.94 & 1.86 & 1.97 & OSAT1SAT2 \\
\hline GY5 & 93 & 1.74 & 1.91 & 1.76 & 1.95 & AOSAT1SAT2 \\
\hline GY8 & 88 & 1.62 & 1.82 & 1.67 & 1.97 & OSAT2 \\
\hline GY10 & 76 & 1.94 & 1.94 & 1.72 & 1.78 & AOSAT1SAT2 \\
\hline GY12 & 88 & 1.93 & 1.94 & 1.93 & 1.58 & AOSAT1 \\
\hline GY13 & 93 & 1.93 & 1.92 & 1.88 & 1.76 & AOSAT1SAT2 \\
\hline GY14 & 90 & 1.82 & 1.87 & 1.85 & 1.88 & AOSAT1SAT2 \\
\hline GY15 & 84 & 1.49 & 1.94 & 1.76 & 1.49 & OSAT1 \\
\hline GY16 & 66 & 1.93 & 1.95 & 1.72 & 1.82 & AOSAT1SAT2 \\
\hline GY17 & 78 & 1.93 & 1.95 & 1.93 & 1.58 & AOSAT1 \\
\hline GY20 & 87 & 1.79 & 1.92 & 1.92 & 1.80 & AOSAT1SAT2 \\
\hline GY21 & 76 & 1.93 & 1.94 & 1.81 & 1.72 & AOSAT1SAT2 \\
\hline GY22 & 69 & 1.84 & 1.93 & 1.37 & 1.51 & $\mathrm{AO}$ \\
\hline GY23 & 86 & 1.83 & 1.94 & 1.91 & 1.81 & AOSAT1SAT2 \\
\hline GY24 & 94 & 1.91 & 1.93 & 1.53 & 1.78 & AOSAT2 \\
\hline GY25 & 94 & 1.88 & 1.93 & 1.52 & 1.22 & $\mathrm{AO}$ \\
\hline GY26 & 89 & 1.54 & 1.58 & 0.57 & 1.01 & Negative \\
\hline
\end{tabular}




\begin{tabular}{|c|c|c|c|c|c|c|}
\hline GY27 & 78 & 1.53 & 1.95 & 1.89 & 1.71 & OSAT1SAT2 \\
\hline GY28 & 92 & 1.83 & 1.93 & 1.59 & 1.54 & $\mathrm{AO}$ \\
\hline GY29 & 89 & 1.70 & 1.93 & 1.57 & 1.73 & AOSAT2 \\
\hline GY30 & 91 & 1.94 & 1.31 & 1.59 & 1.06 & $\mathrm{~A}$ \\
\hline GY32 & 68 & 1.75 & 1.93 & 1.43 & 1.26 & $\mathrm{AO}$ \\
\hline GY37 & 92 & 1.41 & 0.86 & 1.49 & 1.27 & Negative \\
\hline GY38 & 73 & 1.72 & 1.94 & 1.52 & 1.49 & $\mathrm{AO}$ \\
\hline GY39 & 92 & 1.95 & 1.94 & 1.92 & 1.58 & AOSAT1 \\
\hline GY40 & 51 & 1.84 & 1.94 & 1.52 & 1.26 & $\mathrm{AO}$ \\
\hline GY41 & 84 & 1.36 & 1.94 & 1.71 & 1.82 & OSAT1SAT2 \\
\hline GY42 & 67 & 1.91 & 1.93 & 1.89 & 1.93 & AOSAT1SAT2 \\
\hline GY45 & 98 & 1.57 & 1.56 & 1.77 & 1.10 & SAT1 \\
\hline TM2 & 78 & 1.05 & 1.56 & 1.79 & 1.42 & SAT1 \\
\hline TM3 & 95 & 1.94 & 1.92 & 1.92 & 1.89 & AOSAT1SAT2 \\
\hline TM4 & 93 & 1.90 & 1.93 & 1.85 & 1.95 & AOSAT1SAT2 \\
\hline TM5 & 95 & 1.94 & 1.93 & 1.85 & 0.72 & AOSAT1 \\
\hline TM6 & 70 & 1.44 & 1.90 & 1.80 & 1.52 & OSAT1 \\
\hline TM11 & 88 & 1.59 & 1.89 & 1.56 & 1.57 & $\mathrm{O}$ \\
\hline TM12 & 92 & 1.94 & 1.93 & 1.58 & 1.75 & AOSAT2 \\
\hline TM13 & 59 & 1.47 & 1.91 & 1.91 & 1.70 & OSAT1SAT2 \\
\hline TM15 & 68 & 1.90 & 1.85 & 1.91 & 1.82 & AOSAT1SAT2 \\
\hline TM16 & 95 & 1.92 & 1.93 & 1.81 & 1.97 & AOSAT1SAT2 \\
\hline TM18 & 96 & 1.28 & 1.93 & 1.79 & 1.97 & OSAT1SAT2 \\
\hline TM19 & 69 & 1.78 & 1.94 & 1.89 & 1.85 & AOSAT1SAT2 \\
\hline TM20 & 83 & 1.95 & 1.94 & 1.89 & 1.90 & AOSAT1SAT2 \\
\hline TM21 & 51 & 1.71 & 1.14 & 1.51 & 1.52 & A \\
\hline TM22 & 74 & 1.93 & 1.93 & 1.93 & 1.78 & AOSAT1SAT2 \\
\hline
\end{tabular}




\begin{tabular}{|c|c|c|c|c|c|c|}
\hline TM23 & 63 & 1.77 & 1.94 & 1.89 & 1.71 & AOSAT1SAT2 \\
\hline TM24 & 63 & 1.90 & 1.23 & 1.56 & 1.51 & A \\
\hline TM25 & 89 & 1.82 & 1.75 & 1.90 & 1.97 & AOSAT1SAT2 \\
\hline TM26 & 94 & 1.94 & 1.48 & 1.91 & 1.85 & ASAT1SAT2 \\
\hline TM27 & 91 & 1.76 & 1.92 & 1.47 & 1.84 & AOSAT2 \\
\hline TM28 & 76 & 1.29 & 1.92 & 1.46 & 1.81 & OSAT2 \\
\hline TM29 & 67 & 1.34 & 1.91 & 1.84 & 1.86 & OSAT1SAT2 \\
\hline TM30 & 96 & 1.87 & 1.93 & 1.82 & 1.86 & AOSAT1SAT2 \\
\hline KL51 & 74 & 1.45 & 1.92 & 1.87 & 1.85 & OSAT1SAT2 \\
\hline KL53 & 89 & 1.40 & 1.91 & 1.89 & 1.84 & OSAT1SAT2 \\
\hline KL52 & 75 & 1.89 & 1.80 & 1.90 & 1.54 & AOSAT1 \\
\hline NY52 & 76 & 1.38 & 1.82 & 1.51 & 1.46 & $\mathrm{O}$ \\
\hline NY54 & 87 & 1.44 & 1.88 & 1.87 & 1.85 & OSAT1SAT2 \\
\hline NY53 & 80 & 1.52 & 1.93 & 1.44 & 0.79 & $\mathrm{O}$ \\
\hline KL1 & 55 & 1.13 & 1.89 & 1.83 & 1.87 & OSAT1SAT2 \\
\hline KL2 & 71 & 1.40 & 1.93 & 1.89 & 0.54 & OSAT1 \\
\hline KL3 & 85 & 1.80 & 1.46 & 1.49 & 1.29 & A \\
\hline KL4 & 87 & 1.48 & 1.93 & 1.86 & 1.85 & OSAT1SAT2 \\
\hline KL6 & 65 & 1.78 & 1.92 & 1.83 & 1.55 & AOSAT1 \\
\hline KL7 & 68 & 1.38 & 1.88 & 1.84 & 1.42 & OSAT1 \\
\hline KL8 & 54 & 1.91 & 1.94 & 1.81 & 1.82 & AOSAT1SAT2 \\
\hline KL9 & 87 & 1.36 & 1.88 & 1.77 & 1.84 & OSAT1SAT2 \\
\hline KL10 & 69 & 1.93 & 1.90 & 1.72 & 1.79 & AOSAT1SAT2 \\
\hline KL11 & 77 & 1.93 & 1.93 & 1.86 & 1.39 & AOSAT1 \\
\hline KL12 & 95 & 1.84 & 1.93 & 1.88 & 1.94 & AOSAT1SAT2 \\
\hline KL13 & 86 & 1.87 & 1.92 & 1.85 & 1.83 & AOSAT1SAT2 \\
\hline KL14 & 78 & 1.94 & 1.87 & 1.85 & 1.80 & AOSAT1SAT2 \\
\hline
\end{tabular}




\begin{tabular}{|c|c|c|c|c|c|c|}
\hline KL16 & 59 & 1.87 & 1.92 & 1.92 & 1.76 & AOSAT1SAT2 \\
\hline KL17 & 64 & 1.93 & 1.91 & 1.83 & 1.41 & AOSAT1 \\
\hline KL18 & 95 & 1.29 & 1.91 & 1.44 & 1.94 & OSAT2 \\
\hline KL19 & 77 & 1.95 & 1.92 & 1.83 & 1.83 & AOSAT1SAT2 \\
\hline KL20 & 85 & 1.18 & 1.93 & 1.51 & 0.68 & $\mathrm{O}$ \\
\hline KL21 & 77 & 1.30 & 1.89 & 1.84 & 0.99 & OSAT1 \\
\hline KL23 & 74 & 1.52 & 1.92 & 1.86 & 1.77 & OSAT1SAT2 \\
\hline KL25 & 96 & 1.90 & 1.92 & 1.91 & 1.94 & AOSAT1SAT2 \\
\hline KL26 & 95 & 1.85 & 1.91 & 1.76 & 1.27 & AOSAT1 \\
\hline KL28 & 95 & 1.75 & 1.94 & 1.88 & 1.87 & AOSAT1SAT2 \\
\hline KL31 & 69 & 1.90 & 1.92 & 1.82 & 1.72 & AOSAT1SAT2 \\
\hline KL32 & 66 & 1.52 & 1.91 & 1.76 & 1.17 & OSAT1 \\
\hline KL33 & 78 & 1.49 & 1.92 & 1.55 & 1.47 & $\mathrm{O}$ \\
\hline KL34 & 80 & 1.79 & 1.85 & 1.75 & 1.17 & AOSAT1 \\
\hline KL35 & 81 & 1.31 & 1.92 & 1.11 & 1.54 & $\mathrm{O}$ \\
\hline KL37 & 63 & 1.56 & 1.93 & 1.31 & 1.84 & OSAT2 \\
\hline KL38 & 93 & 1.91 & 1.93 & 1.41 & 1.91 & AOSAT2 \\
\hline KL39 & 65 & 1.90 & 1.92 & 1.86 & 1.84 & AOSAT1SAT2 \\
\hline KL40 & 70 & 1.76 & 1.90 & 1.46 & 0.60 & $\mathrm{AO}$ \\
\hline KL45 & 71 & 1.25 & 1.86 & 1.90 & 1.89 & OSAT1SAT2 \\
\hline KL46 & 69 & 1.80 & 1.90 & 1.92 & 1.85 & AOSAT1SAT2 \\
\hline KL48 & 83 & 1.86 & 1.91 & 1.56 & 1.86 & AOSAT2 \\
\hline KL49 & 90 & 1.91 & 1.87 & 1.83 & 1.36 & AOSAT1 \\
\hline KL50 & 99 & 1.86 & 1.88 & 1.90 & 1.84 & AOSAT1SAT2 \\
\hline NY1 & 91 & 1.95 & 1.94 & 1.93 & 1.97 & AOSAT1SAT2 \\
\hline NY2 & 69 & 1.86 & 1.95 & 1.83 & 1.88 & AOSAT1SAT2 \\
\hline NY3 & 54 & 1.74 & 1.93 & 1.91 & 1.71 & AOSAT1SAT2 \\
\hline
\end{tabular}




\begin{tabular}{|c|c|c|c|c|c|c|}
\hline NY4 & 67 & 1.82 & 1.94 & 1.84 & 1.77 & AOSAT1SAT2 \\
\hline NY5 & 77 & 1.46 & 1.94 & 1.81 & 1.49 & OSAT1 \\
\hline NY6 & 67 & 1.85 & 1.93 & 1.89 & 1.88 & AOSAT1SAT2 \\
\hline NY7 & 95 & 1.71 & 1.93 & 1.91 & 1.97 & AOSAT1SAT2 \\
\hline NY10 & 64 & 1.93 & 1.93 & 1.85 & 1.79 & AOSAT1SAT2 \\
\hline NY12 & 93 & 1.93 & 1.91 & 1.87 & 1.86 & AOSAT1SAT2 \\
\hline NY13 & 69 & 1.77 & 1.94 & 1.44 & 1.97 & AOSAT2 \\
\hline NY15 & 86 & 1.93 & 1.95 & 1.94 & 1.93 & AOSAT1SAT2 \\
\hline NY16 & 91 & 1.94 & 1.94 & 1.77 & 1.80 & AOSAT1SAT2 \\
\hline NY17 & 63 & 1.78 & 1.94 & 1.55 & 1.54 & $\mathrm{AO}$ \\
\hline NY18 & 66 & 1.79 & 1.93 & 1.83 & 1.76 & AOSAT1SAT2 \\
\hline NY19 & 90 & 1.84 & 1.93 & 1.40 & 1.28 & $\mathrm{AO}$ \\
\hline NY20 & 78 & 1.79 & 1.92 & 1.80 & 1.83 & AOSAT1SAT2 \\
\hline NY21 & 67 & 1.93 & 1.94 & 1.75 & 1.85 & AOSAT1SAT2 \\
\hline NY22 & 67 & 1.56 & 1.95 & 1.45 & 1.98 & OSAT2 \\
\hline NY25 & 78 & 1.74 & 1.94 & 1.42 & 1.16 & $\mathrm{AO}$ \\
\hline NY27 & 71 & 1.94 & 1.50 & 1.39 & 1.56 & $\mathrm{~A}$ \\
\hline NY29 & 84 & 1.78 & 1.94 & 1.72 & 1.73 & AOSAT1SAT2 \\
\hline NY32 & 57 & 1.54 & 1.87 & 1.49 & 1.52 & $\mathrm{O}$ \\
\hline NY33 & 74 & 1.40 & 0.95 & 1.46 & 1.18 & Negative \\
\hline NY34 & 80 & 1.85 & 1.31 & 1.84 & 1.78 & ASAT1SAT2 \\
\hline NY35 & 71 & 1.79 & 1.92 & 1.41 & 1.82 & AOSAT2 \\
\hline NY37 & 67 & 1.93 & 1.94 & 1.86 & 1.89 & AOSAT1SAT2 \\
\hline NY38 & 57 & 1.84 & 1.94 & 1.46 & 1.86 & AOSAT2 \\
\hline NY40 & 57 & 1.20 & 1.94 & 0.25 & 1.33 & $\mathrm{O}$ \\
\hline NY41 & 61 & 1.38 & 1.94 & -1.05 & 1.44 & $\mathrm{O}$ \\
\hline NY42 & 87 & 1.90 & 1.42 & 1.24 & 1.84 & ASAT2 \\
\hline
\end{tabular}




\begin{tabular}{lllllll}
\hline NY45 & 50 & 1.84 & 1.94 & 1.56 & 1.85 & AOSAT2
\end{tabular}

101

Legend: Sera were collected in 8 districts of south-western of Niger: Makalondi (MK), Gaya (GY), Kollo (KL), Tamou (TM) and Niamey (NY). Sera from Dolé and Tanda were included as originating from Gaya (administrative subdivision that covers these districts), likewise, sera collected in Alambaré were considered as from Tamou that is the administrative subdivision covering this district. Antibody titres were expressed as the final dilution of the tested serum giving $50 \%$ of the mean absorbance value in the virus control wells where test serum was absent. Titres of less than 1.6 (in inverse $\log _{10}$ form) were considered as negative while titres more than 1.6 were considered positive (Hamblin et al., 1986). 